\title{
Unravelling the moons: review of the genera Paratetilla and Cinachyrella in the Indo-Pacific (Demospongiae, Tetractinellida, Tetillidae)
}

\author{
Nadiezhda Santodomingo ${ }^{1,2}$, Leontine E. Becking ${ }^{2,3,4}$ \\ I Department of Life Sciences, The Natural History Museum, Cromwell Road, SW7 5BD London, UK 2 Na- \\ turalis Biodiversity Center, P.O. Box 9517, 2300 RA Leiden. The Netherlands 3 Marine Animal Ecology, \\ Wageningen University, De Elst 1, 6708 WD, Wageningen, The Netherlands 4 Wageningen Marine Research, \\ Ankerpark 27, Den Helder, The Netherlands
}

Corresponding authors: Nadiezhda Santodomingo (n.santodomingo@nhm.ac.uk; nsantodomingo@gmail.com);

Leontine E. Becking (lisa.becking@wur.nl)

Academic editor: M. Pfannkuchen | Received 26 June 2018 | Accepted 20 August 2018 | Published 22 October 2018

http://zoobank.org/BB9D61A3-752B-4570-A1AA-8A790579177C

Citation: Santodomingo N, Becking LE (2018) Unravelling the moons: review of the genera Paratetilla and Cinachyrella in the Indo-Pacific (Demospongiae, Tetractinellida, Tetillidae). ZooKeys 791: 1-46. https://doi. org/10.3897/zookeys.791.27546

\begin{abstract}
Paratetilla bacca (Selenka, 1867) and Cinachyrella australiensis (Carter, 1886) occur in a broad range of marine environments and are allegedly widely distributed species in the Indo-Pacific. We coin the term 'moon sponges' for these species as they are spherical in shape with numerous porocalices resembling the lunar surface. Both species have a complex taxonomic history with high synonymization, in particular by Burton $(1934,1959)$. An examination of the junior synonyms proposed by Burton $(1934,1959)$ was conducted to establish the validity of the names. More than 230 specimens from Naturalis Biodiversity Center were reviewed that belong to the genera Paratetilla and Cinachyrella from marine lakes, coral reefs, and mangroves in Indonesia. The aim of the current study was to untangle the taxonomic history, describe the collection of moon sponges from Indonesia, and develop a key. We extensively reviewed the taxonomic literature as well as holotypes of most of the species synonymized by Burton. The taxonomic history of
\end{abstract}

Copyright N. Santodomingo, L.E. Becking. This is an open access article distributed under the terms of the Creative Commons Attribution License (CC BY 4.0), which permits unrestricted use, distribution, and reproduction in any medium, provided the original author and source are credited. 
Paratetilla spp. and Cinachyrella australiensis showed some cases of misinterpreted synonyms, misidentifications, and lack of detailed descriptions for some species. The conclusion of the revision is that there are three valid species of Paratetilla (P. arcifera, $P$. bacca, and $P$. corrugata) and four valid species of Cinachyrella (C. australiensis, C. porosa, C. paterifera, and C. schulzei) in Indonesia. This is furthermore corroborated by molecular work from previous studies. Paratetilla arcifera Wilson 1925 and C. porosa (Lendenfeld, 1888) are resurrected. A full review of taxonomic history is provided as well as a key for identification of moon sponges from Indonesia. All species are sympatric and we expect that there are undescribed species remaining within the Tetillidae from the Indo-Pacific. Our current review provides the framework from which to describe new species in the genera Paratetilla and Cinachyrella from the Indo-Pacific.

\section{Keywords}

anchialine systems, coral reef, mangrove, marine lake, Porifera

\section{Introduction}

Moon sponges include two good examples of allegedly widely distributed species in the Indo-Pacific: Paratetilla bacca (Selenka, 1867) and Cinachyrella australiensis (Carter, 1886). They are conspicuous dwellers of a broad range of marine environments, including coral reefs, rocky shores, and coastal mangroves, as well as landlocked marine systems called marine lakes (e.g. Hooper et al. 2000, de Voogd and Cleary 2008, de Voogd et al. 2009, Becking et al. 2011). We use the term 'moon sponges' as these species are spherical in shape with numerous porocalices resembling the lunar surface and colored various shades of yellow, orange and brown. This common name has now been adopted by different authors (e.g., Szitenberg et al. 2013). Naturalis Biodiversity Center houses hundreds of moon sponges with a great diversity in morphology that were collected in Indonesia from 2006-2011 with the aim to survey the sponge biodiversity.

The genera Paratetilla and Cinachyrella, belong to the family Tetillidae, suborder Spirophorina, order Tetractinellida, class Demospongiae. As spirophorids, they are characterized by the presence of rugose sigmaspires (van Soest and Hooper 2002). Similar to most tetillids, their globular shape is composed of triaenes and oxeas arranged in a radiate skeleton. Recent revisions of the order and the family have been compiled in the Systema Porifera by van Soest and Hooper (2002) and van Soest and Rützler (2002), respectively. Although 26 nominal genera have been described, only ten valid genera are recognized, which are differentiated by the presence of cortical structures, specialized pore-sieves (porocalices) and composition of the complementary spicules (Rützler 1987, van Soest and Rützler 2002, Carella et al. 2016) (Table 1). The principal types of spicules of this family are: 1 . Megascleres, oxeas and triaenes (pro-, plagio, ortho, and anatriaenes), and 2. Microscleres, microxeas and sigmaspires. Identification at species level is mainly based on the geometry and size range of all spicule types and presence/absence of triaenes (van Soest 1977, Rützler 1987, Rützler and Smith 1992, Lazoski et al. 1999, de Voogd and van Soest 2007, Carella et al. 2016). 
The species P. bacca and C. australiensis share an obscure taxonomic history, including incomplete descriptions, intermingled identifications, and tens of different species synonymized (see synonyms of $C$. australiensis in Burton 1934: 523, and $P$. bacca in Burton 1959: 200). Therefore, we expected that a detailed revision would reveal species lumped together under both taxonomic entities. The aims of this paper are two-fold: (1) to review the taxonomic history of the genus Paratetilla and the species Cinachyrella australiensis, and (2) to identify and describe the different Paratetilla and Cinachyrella species from Indonesia in the Naturalis Biodiversity Center collection.

\section{Materials and methods}

\section{Taxonomic revision}

Literature from 1867 to date was reviewed in order to compile the descriptions of the 11 nominal species for the genus Paratetilla Dendy, 1905. The Cinachyrella species revision was based on the literature cited by Burton (1934), who lumped together 16 nominal species as synonyms of Cinachyrella australiensis (Carter, 1886). The World Porifera Database WPD (van Soest et al. 2018) was used as a valuable guide for consulting the valid species and addressing the literature review. Type material and reference collections deposited at the American Natural History Museum (AMNH) in New York, at the Smithsonian Institution National Museum of Natural History (NMNH) in Washington D.C., the Natural History Museum (NHMUK, formerly BMNH) in London, and the Naturalis Biodiversity Center in Leiden $(\mathbf{R M N H})$, were examined. The majority of the holotypes were studied for the current research; the ones we did not review were either unavailable or the description of the text was clear and comprehensive.

\section{Sampling}

Individuals of Cinachyrella spp. and Paratetilla spp. were collected by snorkelling and SCUBA diving during expeditions to Bali (2003), Bunaken (Sulawesi, 2006), Pulau Seribu (Java, 2005), Raja Ampat (Papua, 2007), Berau (East Kalimantan, 2008), and Ternate (Moluccas, 2009). Sampling was systematically achieved in marine habitats such as coral reefs and mangroves, and within marine lakes (Raja Ampat and Berau). Specimens were photographed in situ and notes made on morphological and ecological features such as color, size, depth, and substrate. A total of 237 specimens were collected and preserved in ethanol 70\%; an additional 11 specimens from the Naturalis Biodiversity Center collection from Indonesia and elsewhere were reviewed as well as 20 type specimens. Table 2 provides an overview of sample numbers per species and Suppl. material 1 (Table S1) provides full collection details per sample. 
Table I. Valid genera of Tetillidae Sollas, 1888 and principal characteristics used to distinguish them. (+) present, (-) absent. (AN) Antarctic, (AT) Atlantic, (CA) Caribbean, (IP) Indo-Pacific. Modified from Rützler (1987), van Soest and Rützler (2002), Carella et al. (2016). Number of valid species consulted at the World Porifera Database (van Soest et al. 2018; accessed 04 Jun 2018).

\begin{tabular}{|c|c|c|c|c|c|}
\hline Genus & $\begin{array}{c}\text { Cortex } \\
\text { (reinforced by) }\end{array}$ & $\begin{array}{l}\text { Porocalices } \\
\text { (shape) }\end{array}$ & $\begin{array}{l}\text { Accessory } \\
\text { spicules }\end{array}$ & \begin{tabular}{|c|} 
Valid \\
speCies
\end{tabular} & Distribution \\
\hline Tetilla Schmidt, 1868 & - & - & - & 54 & AT, CA, IP \\
\hline Craniella Schmidt, 1870 & $+\begin{array}{c}\text { (minute smooth } \\
\text { oxea })\end{array}$ & - & - & 42 & $\begin{array}{l}\text { AN, AT, } \\
\text { CA, IP }\end{array}$ \\
\hline Cinachyra Sollas, 1886 & $+\begin{array}{c}\text { (minute smooth } \\
\text { oxea })\end{array}$ & + (flask) & - & 3 & AN, AT \\
\hline Paratetilla Dendy, 1905 & - & $\begin{array}{c}+ \text { (hemi-spherical } \\
\text { or narrow) }\end{array}$ & + (calthrop-like) & 5 & IP \\
\hline Cinachyrella Wilson, 1925 & - & + (hemi-spherical) & - & 42 & AT, CA, IP \\
\hline Amphitethya Lendenfeld, 1907 & + (amphiclads) & - & + (amphiclads) & 2 & IP \\
\hline Fangophilina Schmidt, 1880 & - & $\begin{array}{c}+ \text { (differentiated, } \\
\text { narrow) }\end{array}$ & - & 4 & AT, CA, IP \\
\hline Acanthotetilla Burton, 1959 & $\begin{array}{c}+ \\
\text { (megacanthoxea) }\end{array}$ & + (narrow) & + (megacanthoxea) & 7 & AT, CA, IP \\
\hline Antarctotetilla Carella et al., 2016 & $\begin{array}{c}\text { pseudocortex } \\
\text { (oxeas loosely } \\
\text { arranged) }\end{array}$ & - & - & 4 & AN \\
\hline Levantiniella Carella et al., 2016 & - & + (small, rounded $)$ & - & 1 & AN \\
\hline
\end{tabular}

Table 2. Number of samples reviewed per taxon. The column "Indonesia" refers to all samples recently collected in Indonesia (years 2006-2011), "other material" to older specimens in museum collections from Indonesia or other countries; "types" refer to type specimens of valid species and junior synonyms.

\begin{tabular}{l|c|c|c|c}
\hline \multicolumn{1}{c|}{ Species } & Indonesia & Other material & Types & Total \\
\hline Paratetilla bacca & 38 & 4 & 4 & 46 \\
\hline Paratetilla arcifera & 21 & 4 & 1 & 26 \\
\hline Cinachyrella australiensis & 117 & 3 & 9 & 129 \\
\hline Cinachyrella porosa & 47 & - & 5 & 52 \\
\hline Cinachyrella paterifera & 14 & - & 1 & 15 \\
\hline Total & 237 & 11 & 20 & $\mathbf{2 6 8}$ \\
\hline
\end{tabular}

\section{Morphology}

Radial and superficial histological sections of sponges were hand cut with a surgical blade; tissue sections were dried on a heat-plate more than 1 hour, mounted in Durcupan ACR resin and examined using light microscopy. Spicule preparations were made by dissociation of a fragment of sponge in sodium hypochlorite and consecutive washing steps, three times in distilled water, twice in 70\% ethanol, and suspending in 95\% ethanol. The dissociated spicules were dropped onto glass microscope slides, dried and mounted in Durcupan for light microscopy. Spicule preparations for Scanning Electron Microscopy (SEM) were made after two extra washing steps with 95\% ethanol. Spicule dimensions and character definitions follow Rützler (1987), Rützler and Smith (1992) and van Soest and Rützler (2002). Spicule dimensions are based on 25 measurements for type specimens and for reference material. Data are given as minimum-mean-maximum in the text. 


\section{Results and discussion}

\section{Systematic descriptions}

\section{Order Astrophorida \\ Family Tetillidae Sollas, 1888 \\ Genus Paratetilla Dendy, 1905}

The genus Paratetilla was established by Dendy (1905) based on the presence of a layer of modified triaenes (calthrops-like). Eleven nominal species have been described with this diagnostic character: Stelletta bacca Selenka, 1867, Tethya merguiensis Carter, 1883, Tetilla ternatensis Kieschnick, 1896, Tetilla amboinensis Kieschnick, 1898, Tetilla violacea Kieschnick, 1898, Tetilla rubra Kieschnick, 1898, Paratetilla cineriformis Dendy, 1905, Paratetilla eccentrica Row, 1911, Paratetilla aruensis Hentschel, 1912, Paratetilla corrugata Dendy, 1922, and Paratetilla lipotriaena de Laubenfels, 1954. The revision of the taxonomic history of these species reveals that some ambiguous statements have been made (Table 3).

Recent checklists and biodiversity studies in the Indo-Pacific have only recorded P. bacca, following Burton's taxonomic decision in 1959 to synonymize all nominal Paratetilla species except $P$. lipotriaena. Two exceptions were found in the literature, the review by Desqueyroux-Faundez (1981) of Topsent's material (1897) from Amboina Island, who identified it as Paratetilla merguiensis, and the inventory of sponges from South China Sea by Hooper et al. (2000), where P. arcifera was listed in addition to $P$. bacca.

Table 3. Historic milestones in the taxonomy of the genus Paratetilla Dendy, 1905. Asterisk $\left(^{*}\right)$ indicates misidentification of Cinachyrella specimens as Paratetilla.

\begin{tabular}{c|c|l}
\hline Year & Author & \multicolumn{1}{c}{ Descriptions / Statements } \\
\hline 1867 & Selenka & $\begin{array}{l}\text { Description of Stelletta bacca. Selenka's material was collected in Samoa Island and due to the } \\
\text { presence of triaenes this species was associated to the family Corticatae (now Astrophorida: } \\
\text { Ancorinidae). The description is brief but the sketches included are illustrative, including } \\
\text { "Vierstrahler" (=calthrop-like) spicules. Sigma-like spicules are neither mentioned in the } \\
\text { description nor drawn in the figures. Currently, type specimen could not be located. }\end{array}$ \\
\hline 1883 & Carter & $\begin{array}{l}\text { Description of Tethya merguiensis, including sigmaspires, calthrop-like spicules, oxeas and } \\
\text { triaenes and their respective measurements and sketches. }\end{array}$ \\
\hline 1887 & Ridley & $\begin{array}{l}\text { In his monograph, Ridley kept Stelletta bacca in the genus Stelletta. The diagnostic } \\
\text { characteristic for Stelletta for his decision was the absence of bacillar or acerate flesh-spicules. } \\
\text { He also noticed that the Samoan Stelletta "is probably a Tethya, as its stellate agrees with the } \\
\text { large stellate of that genus, and its forks are rare and probably foreign to the sponge" (see } \\
\text { footnote in Ridley 1884, p. 472). }\end{array}$ \\
\hline 1888 & Sollas & $\begin{array}{l}\text { Statement about Stelletta bacca mentioning that it can hardly belong to Stelletta genus } \\
\text { without further argumentation. }\end{array}$ \\
$\begin{array}{l}\text { Establishment of Family Tetillidae, type genus Tetilla Schmidt, 1868. Sponges in this family } \\
\text { have sigmaspires (microscleres) and slender protriaenes (megascleres) as diagnostic characters. } \\
\text { In this family Sollas included the species Craniella (Alcyonium) cranium Müller (1789), } \\
\text { species under the genus Tethya by Lamarck (1815) and Gray (1867), and species within the } \\
\text { group Tethyina Carter (1875). Carter's material of Tethya merguiensis was redescribed and } \\
\text { transferred to the genus Tetilla, as Tetilla merguiensis. Tethya cranium var. australiensis was } \\
\text { redescribed as Tetilla (?) australiensis. Many other species were also described by Sollas within } \\
\text { this family. }\end{array}$ \\
\hline
\end{tabular}




\begin{tabular}{|c|c|c|}
\hline Year & Author & Descriptions / Statements \\
\hline $1896^{*}$ & Kieschnick & $\begin{array}{l}\text { Description of Tetilla ternatensis based on material from Ternate Island (Indonesia); he } \\
\text { mentioned "Vierstrahler" (=calthrops). }\end{array}$ \\
\hline 1897 & Lindgren & $\begin{array}{l}\text { Tethya merguiensis Carter, } 1873 \text { as junior synonym to Stelletta bacca, based on a comment } \\
\text { by Sollas (1888, p. 205) of his monograph: "Stelletta bacca, Selenka, which Vosmaer } \\
\text { correctly excludes from Stelletta, while Ridley includes it, is as mounted preparations show, } \\
\text { identical with Tetilla merguiensis, Carter". However, neither Ridley (1884) nor Vosmaer } \\
\text { (1887) supported their inclusion or exclusion of the species with any description of the } \\
\text { Selenka specimen, but apparently, they were based merely on the published description. It is } \\
\text { remarkable that Sollas in the same monograph (1888) identified the Challenger specimens } \\
\text { as Tetilla merguiensis, including for the first time this genus and species under the family } \\
\text { Tetillidae due to the characteristic sigmaspires. }\end{array}$ \\
\hline $1898^{*}$ & Lindgren & $\begin{array}{l}\text { Redescription of Tetilla bacca, with Tetilla merguiensis as junior synonym, including material } \\
\text { of Torres Straits (North Australia), two localities at Java (Indonesia) and Carter's specimens } \\
\text { from Mergui Archipelago. Size range for each station is shown for oxeas and triaenes, arguing } \\
\text { that larger spicules are found to the west while smaller sizes to the east. Redescription of } \\
\text { Tetilla ternatensis based on Java material. It is remarkable that he mentioned the presence of } \\
\text { numerous microxeas }(240 \times 4 \mu \mathrm{m}) \text { and sigmaspires } 24 \mu \mathrm{m} \text {. }\end{array}$ \\
\hline 1898 & Kieschnick & $\begin{array}{l}\text { Description of Tetilla amboinensis, Tetilla violacea and Tetilla rubra from Amboina Island, } \\
\text { all of them with "Vierstrahler" (=calthrop-like) spicules. T. amboinensis and T. violacea with } \\
\text { calthrops in a layer below the surface of the sponge; while the former is characterized by } \\
\text { smaller number of triaenes and bundles of oxeas up to the surface of the sponge, the latter } \\
\text { by very abundant triaenes, bundles of oxeas projected over the surface of the sponge, and } \\
\text { a typical violet color. T. rubra separated from the other two by its brick-red color and with } \\
\text { calthrops mainly on the basal part of the sponge. }\end{array}$ \\
\hline 1900 & Kieschnick & Extensive description of the same three new species. \\
\hline $1900^{*}$ & Thiele & $\begin{array}{l}\text { Redescription of Tetilla ternatensis Kieschnick, 1896. Thiele drew attention on the } \\
\text { misidentification of T. ternatensis by Lindgren (1898), clarifying that Lindgren specimens } \\
\text { exhibited microxea resembling Tetilla australiensis (Carter, 1886). Moreover, Thiele proposed } \\
\text { that T. ternatensis, as well as Kieschnick's species T. amboinensis, T. violacea and T. rubra, } \\
\text { should be junior synonyms of T. bacca arguing that T. bacca shows a large morphological } \\
\text { variability. }\end{array}$ \\
\hline $1900^{*}$ & Kirkpatrick & $\begin{array}{l}\text { Extension of the geographical range of T. bacca and T. ternatensis to Christmas Island. T. } \\
\text { bacca specimens were described with identical spicules to Lindgren's (1898) material from } \\
\text { Java. T. ternatensis also similar to Lindgren's (1898) material of T. ternatensis. }\end{array}$ \\
\hline $1903^{*}$ & Lendenfeld & $\begin{array}{l}\text { Designation of a new species Tetilla lindgreni based on Lindgren's specimens (1898) from Java } \\
\text { and Kirkpatrick's specimens (1900) from Christmas islands, both identified as T. ternatensis } \\
\text { without calthrops and with small microxeas. Thus, Lendenfeld concluded that those } \\
\text { specimens belong to a new species (T. lindgreni) because they did not show calthrops as in the } \\
\text { original description of Kieschnick (1896). Junior synonyms for Tetilla bacca, including the } \\
\text { material of Selenka, Carter, Sollas, and Kirkpatrick. T. ternatensis and T. violacea described by } \\
\text { Kieschnick and recorded by Thiele (1900) were also included as junior synonyms of T. bacca. } \\
\text { Tetilla amboinensis Kieschnick (1898) was transferred to genus Cinachyra and T. rubra was } \\
\text { established as its junior synonym. }\end{array}$ \\
\hline 1905 & Dendy & $\begin{array}{l}\text { The genus Paratetilla was erected within the family Tetillidae, based on the presence of } \\
\text { calthrop-like spicules. Thus, Tetilla bacca is transferred to Paratetilla genus, including their } \\
\text { junior synonyms T. merguiensis, as well as the three Kieschnick's species T. ternatensis, T. } \\
\text { amboinensis and T. violacea based on Thiele's annotation (1903). Description of Paratetilla } \\
\text { cineriformis based on material from Gulf of Manaar (Sri Lanka). Although the spicules shown } \\
\text { by P. cineriformis resembled T. merguiensis, Dendy (1905) argues that the general aspect of } \\
\text { the sponge was quite different as porocalices have no specific arrangement and the layer of } \\
\text { calthrops was more irregular than in Carter's species. }\end{array}$ \\
\hline 1907 & Lendenfeld & $\begin{array}{l}\text { The genus Amphytethya was created based on its characteristic amphitriaenes. Many other } \\
\text { species under the genus Cinachyra, Fangophilina and Tetilla were described. }\end{array}$ \\
\hline 1911 & Row & $\begin{array}{l}\text { Description of Paratetilla eccentrica from the Red Sea. Cortical triaenes (= calthrop-like) with } \\
\text { high modifications, in some cases even becoming into "walking-sticks". }\end{array}$ \\
\hline 1912 & Hentschel & $\begin{array}{l}\text { Description of Paratetilla aruensis from Aru- and Kei- Islands (Indonesia), with characteristic } \\
\text { amphitriaenes. Relocation of the genus Amphitethya Lendenfeld, } 1907 \text { as a junior synonym } \\
\text { of Paratetilla. }\end{array}$ \\
\hline
\end{tabular}




\begin{tabular}{|c|c|c|}
\hline Year & Author & Descriptions / Statements \\
\hline 1922 & Dendy & $\begin{array}{l}\text { All nominal species with calthrop-like spicules were synonymized to Paratetilla bacca, except } \\
\text { for } P \text {. aruensis Hentschel, } 1912 \text {. Two varieties were identified: } P \text {. bacca var. violacea based on } T \text {. } \\
\text { violacea characteristics, and the new variety } P \text {. bacca var. corrugata from Diego Garcia in the } \\
\text { Indian Ocean. }\end{array}$ \\
\hline 1925 & Wilson & $\begin{array}{l}\text { Description of Paratetilla arcifera from Philippines. Wilson recognized as valid four } \\
\text { additional species: P. bacca (Selenka, 1867), P. amboinensis (Kieschnick, 1898), P. cineriformis } \\
\text { (Dendy, 1905) and P. eccentrica (Row, 1911). However, he also commented that P. bacca is a } \\
\text { comprehensive variable species, as previously proposed by Thiele (1903) and later established } \\
\text { by Dendy (1922). Establishment of Cinachyrella genus. Validation of the genus Amphitethya } \\
\text { Lendenfeld, 1907. }\end{array}$ \\
\hline 1954 & de Laubenfels & $\begin{array}{l}\text { Description of Paratetilla lipotriaena from Micronesia (West-Central Pacific), characterized by } \\
\text { variable calthrop-like spicules and the absence of triaenes, and relatively similar to P. eccentrica } \\
\text { Row, } 1911 \text {. }\end{array}$ \\
\hline 1959 & Burton & $\begin{array}{l}\text { All nominal species described within the genus Paratetilla were included as synonyms of } P \text {. } \\
\text { bacca, except for } P \text {. lipotriaena. }\end{array}$ \\
\hline 1987 & Rützler & $\begin{array}{l}\text { Review of Family Tetillidae, including seven genera (all except for Fangophilina). Nomination } \\
\text { of Paratetilla cineriformis as type species of genus Paratetilla. }\end{array}$ \\
\hline 1994 & $\begin{array}{c}\text { Hooper and } \\
\text { Wiedenmayer }\end{array}$ & Review of all Paratetilla bacca synonyms based on Burton (1959) taxonomic decision. \\
\hline 2002 & $\begin{array}{c}\text { van Soest and } \\
\text { Rützler }\end{array}$ & $\begin{array}{l}\text { Review of the eight genera included within family Tetillidae. Although Paratetilla characters } \\
\text { were a combination of two descriptions, a paragraph in the discussion included the } \\
\text { size differences between both Selenka's and Carter's material (Stelletta bacca and Tethya } \\
\text { merguiensis, respectively). The origin of calthrop-like spicules was also discussed as probably } \\
\text { modified plagiotriaenes resembling some Cinachyrella species, arguing the possibility of the } \\
\text { inclusion of the widespread species Paratetilla bacca within Cinachyrella genus. }\end{array}$ \\
\hline 2008 & $\begin{array}{c}\text { van Soest and } \\
\text { Beglinger }\end{array}$ & $\begin{array}{l}\text { Redescription of Paratetilla corrugata based on material from the Gulf of Oman, and } \\
\text { giving validity to the variety P. bacca var. corrugata by Dendy (1922). The presence of } \\
\text { trichodragmata is characteristic of this species. }\end{array}$ \\
\hline 2018 & $\begin{array}{l}\text { van Soest et } \\
\text { al. (WPD) }\end{array}$ & $\begin{array}{l}\text { Junior synonyms for Paratetilla bacca (Selenka, 1867): Tetilla bacca (Selenka, 1867), } \\
\text { Stelletta bacca bacca Selenka, 1867, Tethya merguiensis Carter, 1883, Stelletta bacca Selenka, } \\
\text { 1887, Tetilla violacea Kieschnick, 1896, Tetilla ternatensis Kieschnick, 1896, Tetilla rubra } \\
\text { Kieschnick, 1898, Paratetilla cineriformis Dendy, 1905, Paratetilla eccentrica Row, 1911, } \\
\text { Paratetilla arcifera Wilson, 1925. Other accepted Paratetilla species in WPD: Paratetilla } \\
\text { amboinensis (Kieschnick, 1898), Paratetilla aruensis Hentschel, 1912, Paratetilla corrugata } \\
\text { Dendy, 1922, Paratetilla lipotriaena de Laubenfels, } 1954 .\end{array}$ \\
\hline 2018 & This study & $\begin{array}{l}\text { Paratetilla species from Indonesia: Paratetilla bacca (Selenka, 1867), Paratetilla arcifera } \\
\text { Wilson, 1925, and Paratetilla corrugata Dendy, } 1922 \text { (not observed in our Indonesian } \\
\text { material), Paratetilla aruensis Hentschel, } 1912 \text { with amphitriaenes, it is suggested to be } \\
\text { transferred to Amphitethya. }\end{array}$ \\
\hline
\end{tabular}

\section{Paratetilla bacca (Selenka, 1867)}

Figs 1, 2

Stelletta bacca Selenka, 1867: 569, pl. xxxv, figs 14, 15 (type not found, material from type locality seen).

Tethya merguiensis Carter, 1883: 366, pl. xv, figs 6-8; Carter, 1887: 80 (type seen). Tetilla merguiensis; Sollas, 1888: 14; Topsent, 1897: 441, pl. xviii, fig. 4-5, pl. xxi figs 34.

Tetilla ternatensis Kieschnick, 1896: 527. Thiele, 1900: 39, pl. ii, fig 13; Not Tetilla ternatensis Lindgren, 1898: 329 pl. 17, fig. 14; pl. 19, Fig. 25 a-e, a', b'.

Tetilla bacca; Lindgren, 1897: 485; Lindgren, 1898: 328; Thiele, 1900: 39, pl. ii, fig 13; Kirkpatrick, 1900: 132 (material seen); Lendenfeld, 1903: 19. 
Tetilla amboinensis Kieschnick, 1898: 10.

Tetilla violacea Kieschnick, 1898: 15.

Tetilla rubra Kieschnick, 1898: 18.

Paratetilla cineriformis Dendy, 1905: 97, pl. iii, fig. 7 (type seen).

Paratetilla eccentrica Row, 1911: 306, pl. xxxv, fig. 1, pI. xxxvi, fig. 8 (type seen).

Cinachyra amboinensis; Hentschel, 1912: 331.

Paratetilla bacca; Dendy, 1922: 21 (material seen).

Paratetilla bacca var. violacea; Dendy, 1922: 22, pl. 1, fig. 6 (material seen).

Paratetilla lipotriaena de Laubenfels, 1954: 244, text figure no. 168 (type seen).

Material examined. Neotype ZMA.POR.13029, Tutuila Island, American Samoa. Holotype of first junior synonym Tethya merguiensis Carter, 1883 (?) NHMUK 1894.11.16.17, Mergui Archipelago, Myanmar. Holotype NHMUK 1954.2.23.106 Gulf of Manaar, Sri Lanka (as Paratetilla cineriformis Dendy, 1905). NHMUK unreg. type, Crossland Collection, Red Sea (as Paratetilla eccentrica Row, 1911). NHMUK 1898.12.20.19, Flying Cove Fish, Christmas Islands (as Tetilla bacca=Paratetilla merguiensis Kirkpatrick, 1900). NHMUK 1921.11.7.10, Sealark Sponges, Indian Ocean (as Paratetilla bacca var. violacea). Holotype USNM 23049, East part of Lagoon, Ponape, Caroline Islands, 1 Aug 1949 (as Paratetilla lipotriaena de Laubenfels, 1954). INDONESIA. Bali, Bali reef, RMNH.POR.1732; East Kalimantan, Berau reef, RMNH. POR.11281, RMNH.POR.11282, RMNH.POR.11283; Kakaban Lake, RMNH. POR.11289, RMNH.POR.11290, RMNH.POR.11291, RMNH.POR.11292, Haji Buang Lake, RMNH.POR.11284, RMNH.POR.11287, RMNH.POR.11288, RMNH.POR.11285, RMNH.POR.11286, RMNH.POR.3515. Sulawesi, Bunaken reef, RMNH.POR.3100, RMNH.POR.3106, RMNH.POR.3115; Bunaken mangrove, RMNH.POR.2819; Spermonde Archipelago, ZMA.POR.13221. Ternate, Ternate reef, RMNH.POR.5344, RMNH.POR.5467. West Papua, Wallace Lake, RMNH. POR.11293, RMNH.POR.11294, RMNH.POR.11295; Outside Wallace Lake, RMNH.POR.11296, RMNH.POR.11297, RMNH.POR.11298; Ctenophore Lake, RMNH.POR.11302; Gam Mangrove, RMNH.POR.11299, RMNH.POR.11300, RMNH.POR.11301; Outside Ctenophore Lake, RMNH.POR.11303; Big Caulerpa Lake, RMNH.POR.11304; Gam Island, RMNH.POR.11305, RMNH.POR.11306, RMNH.POR.11307.

Other material: East Kalimantan, Makassar Straits, ZMA.POR.1735, Siboga Expedition, St. 81. Singapore, RMNH.POR.2506, RMNH.POR.2512. Western Indian Ocean, ZMA.POR.20673.

Description. External morphology. Globular sponges, size between 1 and $5 \mathrm{~cm}$ in diameter. Surface hispid due to the projecting spicules, covered by numerous porocalices (Figure 1A, B). Porocalices are bowl-shape, with oval to circular apertures, up to $5 \mathrm{~mm}$ in diameter and $7 \mathrm{~mm}$ deep, numerous, scattered uniformly over the surface of the sponge; in preserved material, some porocalices are closed and only a narrow aperture is visible giving to the sponge a rough appearance. External color generally brown when alive, which turns dark brown in ethanol, choanosome light brown, and 


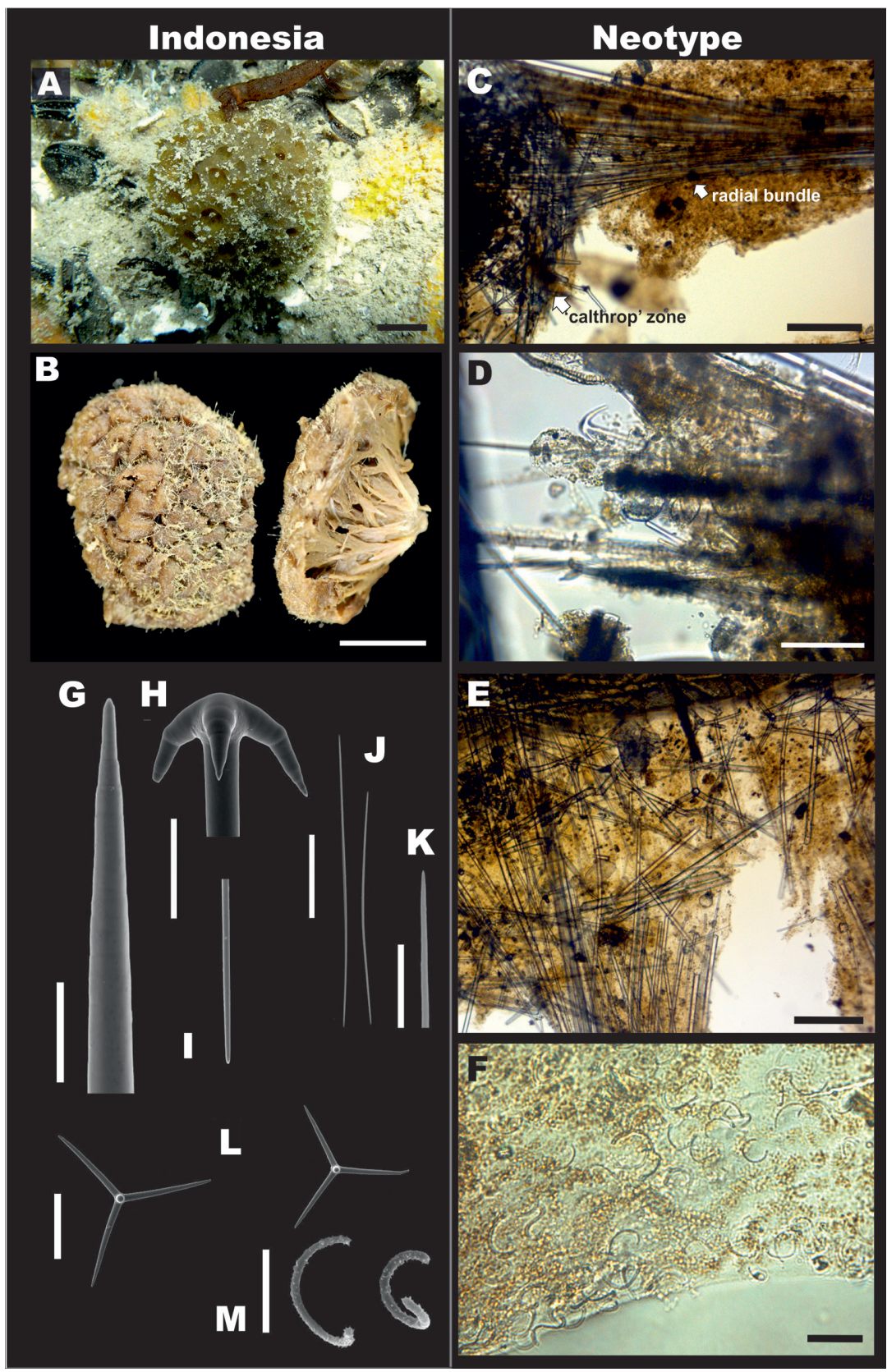

Figure I. Paratetilla bacca. A,B, G-M RMNH.POR.11292, Kakaban Lake, Indonesia (left side). C-F neotype material of Paratetilla bacca, ZMA.POR.13029, Tutuila Island, American Samoa (right side). A in situ photograph B preserved specimen showing the porocalices (scale bar $1 \mathrm{~cm}$ ) $\mathbf{C}$ skeleton showing oxeas, calthrops and triaenes $\mathbf{D}$ skeleton, showing anatriaenes, protriaenes and oxeas $\mathbf{E}$ skeleton showing detail of the 'calthrop' zone $\mathbf{F}$ sigmaspires $\mathbf{G}$ oxea, detail $\mathbf{H}, \mathbf{I}$ anatriaene, cladus and rhabd end, J thin microxea, $\mathbf{K}$ thin microxea, detail $\mathbf{L}$ calthrops $\mathbf{M}$ sigmaspires. Scale bars: $200 \mu \mathrm{m}(\mathbf{A}-\mathbf{C}) ; 40$ $\mu \mathrm{m}(\mathbf{D}, \mathbf{G}-\mathbf{I}) ; 200 \mu \mathrm{m}(\mathbf{E}) ; 20 \mu \mathrm{m}(\mathbf{F}) ; 50 \mu \mathrm{m}(\mathbf{J}) ; 10 \mu \mathrm{m}(\mathbf{K}, \mathbf{M}) ; 100 \mu \mathrm{m}(\mathbf{L})$. 
has a 'dried out' appearance (Figure 1B). Numerous small dark brown granules in the tissue (Figure 1E, F). Consistency compact.

Skeleton. No cortex. Choanosomal skeleton composed by bundles of oxeas and triaenes radiating from a central core, $1 / 5-1 / 3$ of the diameter of the sponge.

Megascleres. The material from Indonesia and the type of $P$. merguiensis have oxeas 850-3085.3-4500 $\mu \mathrm{m} \times$ 5-41.5-65 $\mu \mathrm{m}$ (Table 4, Figure 1E, D, G). Anatriaenes always present, very abundant, cladi stout, slightly flattened, 20-62.6-100 $\mu \mathrm{m} \times$ $12.5-48.3-75 \mu \mathrm{m}$, long rhabd up to $6000 \times 20 \mu \mathrm{m}$, tapering to dimensions much less than $1 \mu \mathrm{m}$ (Figure 1H, I). Protriaenes scarce in some specimens and absent in the type specimen; when present, they exhibit two different shapes, the first one with stouter and smaller cladi, the second one with thinner and larger cladi (27.5-53.9-100 $\mu \mathrm{m} \times$ $37.5-107.4-200 \mu \mathrm{m} \times 2.5-6.5-12.5 \mu \mathrm{m}$ ), rhabd up to $5850 \times 15 \mu \mathrm{m}$, tapering to dimensions of $<1 \mu \mathrm{m}$. Calthrop-like short shafted triaenes, three types are distinguished with a wide range of sizes, from which measurements are shown as a general summary (Table 4). In the first type, four rays can be recognized (Figure 1L), three of them large, up to $400-600 \mu \mathrm{m}$, and a short one up to $100 \mu \mathrm{m}$ long, usually pointing down to the centre of the body; the second one with three rays, almost the same length up to 400 $\mu \mathrm{m}$; and the third one with three rays as well, two of them in an angle of $180^{\circ}$ and the other one perpendicular, 50-100 $\mu \mathrm{m}$. The calthrops are located immediately below the surface, constituting more or less a homogeneous layer.

Microscleres. Thin microxeas are common, 105-241.6-380 $\mu \mathrm{m}$, 'hair-like'. Sigmaspires, 10-14.1-25 $\mu \mathrm{m}$, C-S shape (Figure 1F, M).

Ecology. Inhabiting all studied environments in Indonesia, including coral reefs, mangroves, and marine lakes. Specimens more common in mangroves and marine lakes, and shallow reef flats where they are usually found on dead coral skeletons or coral rubble, typically ranging in depth from $0-5 \mathrm{~m}$. No specimens collected from deeper coral reefs in Indonesia.

Distribution. Paratetilla bacca has a wide distribution in Indonesia, including Berau, Bunaken, Raja Ampat, Ternate, and Java. Previous Indonesian records are from Spermonde Archipelago (Becking et al. 2006), Berau (de Voogd et al. 2009), and Raja Ampat (Becking 2008). In addition, this species has also been reported from Seychelles Islands (Thomas 1973), Southwest Madagascar (Vacelet et al. 1976), Zanzibar (Pulitzer-Finali 1993), Thailand (Putchakarn 2007), Singapore (Lim et al. 2008), Philippines (Longakit et al. 2005) (Figure 2).

Remarks. We did not succeed in locating the holotype of Paratetilla bacca, despite concerted effort. At this time, we assume that the type is no longer available. The description by Selenka of the type specimen does not mention the occurrence of any type of sigmaspires. It is a matter of speculation whether Lindgren (1897) actually examined Selenka's material to propose Carter's species Paratetilla merguensis as a junior synonym to Paratetilla bacca, or whether he based his conclusion merely on the literature. It is possible that sigmaspires may have been overlooked by Selenka in his original description and drawings, yet the arrangement of the megascleres in the skeleton shows a clear similarity with Carter's species P. merguensis (Suppl. material 2, Figure S1). In contrast 
to Selenka's description, Carter (1883) included a complete and detailed account of P. merguiensis, which was verified through examination of two slides deposited in the NHM collection (NHMUK 1894.11.16-17); few oxeas are complete in these slides (most broken), therefore limited variation of this character was observed. For most of spicule types enough measurements were possible. Although we did not succeed finding Selenka's type, we did examine one specimen and its associated slide preparation from Samoa identified as P. bacca (ZMA.POR.13029), which has all the characteristic spicules, including sigmaspires, that are present in our specimens from Indonesia (Figure 1C-F). This material is designated here with the status of neotype following the rules of the International Code of Zoological Nomenclature, article 75. Therefore, we conclude that $P$. bacca is a valid species, and subsequent species should be designed as junior synonyms. In all of our Paratetilla samples, we have furthermore not encountered one specimen without sigmaspires. Here, we show the measurements of the holotype of $P$. merguiensis, as well as specimens from different localities in Indonesia (Table 4). Although there is a large variation in spicules sizes among the different localities, there was also great intra-specific variation and we did not find any reason to declare the validity of any junior synonym included in this revision. In general, populations from marine lakes (Kakaban and Haji Buang) exhibit smaller spicules in comparison with their reefal counterparts at the same localities (Table 4). This variation could be a response to different environmental conditions within the marine lakes (Becking et al. 2011), or a consequence of genetic selection after isolation of these populations about 8000-10000 years ago (Dawson and Hamner 2005, Becking et al. 2013, Becking et al. 2016), or a synergistic effect between environmental and genetic factors.

According to the WPD (van Soest et al. 2018), other four valid Paratetilla species are P. amboinensis (Kieschnick, 1898), P. lipotriaena de Laubenfels, 1954, P. corrugata Dendy, 1922 and P. aruensis Hentschel, 1912. Based on the description of $P$. amboinensis (Kieschnick, 1898), the shape and skeleton features exhibited by this species fit within the current diagnosis of $P$. bacca, therefore we recommend that these two species should be synonymized. The species $P$. lipotriaena was erected by de Laubenfels based on the absence of triaenes. Our examination of the type specimen (USNM 23049) revealed the presence of triaenes and the same characters as $P$. bacca, therefore we have synonymized this species with $P$. bacca. On the other hand, P. bacca can be distingished from $P$. corrugata Dendy, 1922, because of the abundant trichodragmata exhibited by the latter species. Consequently, $P$. corrugata can still be considered a valid species. Finally, the status of $P$. aruensis Hentschel, 1912 within this genus should be reconsidered. After examination of two slides available at the NHMUK, no calthrops were found, only the typical amphitriaenes originally described for this species. Amphitriaenes make this species more similar to the genus Amphitethya instead of Paratetilla. Further examination of specimens would corroborate our preliminary conclusion.

In a molecular phylogenetic study, which was based in part on specimens that we review in the current study (see Suppl. material 1, Table S1 for corresponding GenBank numbers), Schuster et al. (2017) distinguishes P. bacca as a monophyletic clade in the Tetillidae. Due to the wide distribution of this species and large intraspecific 


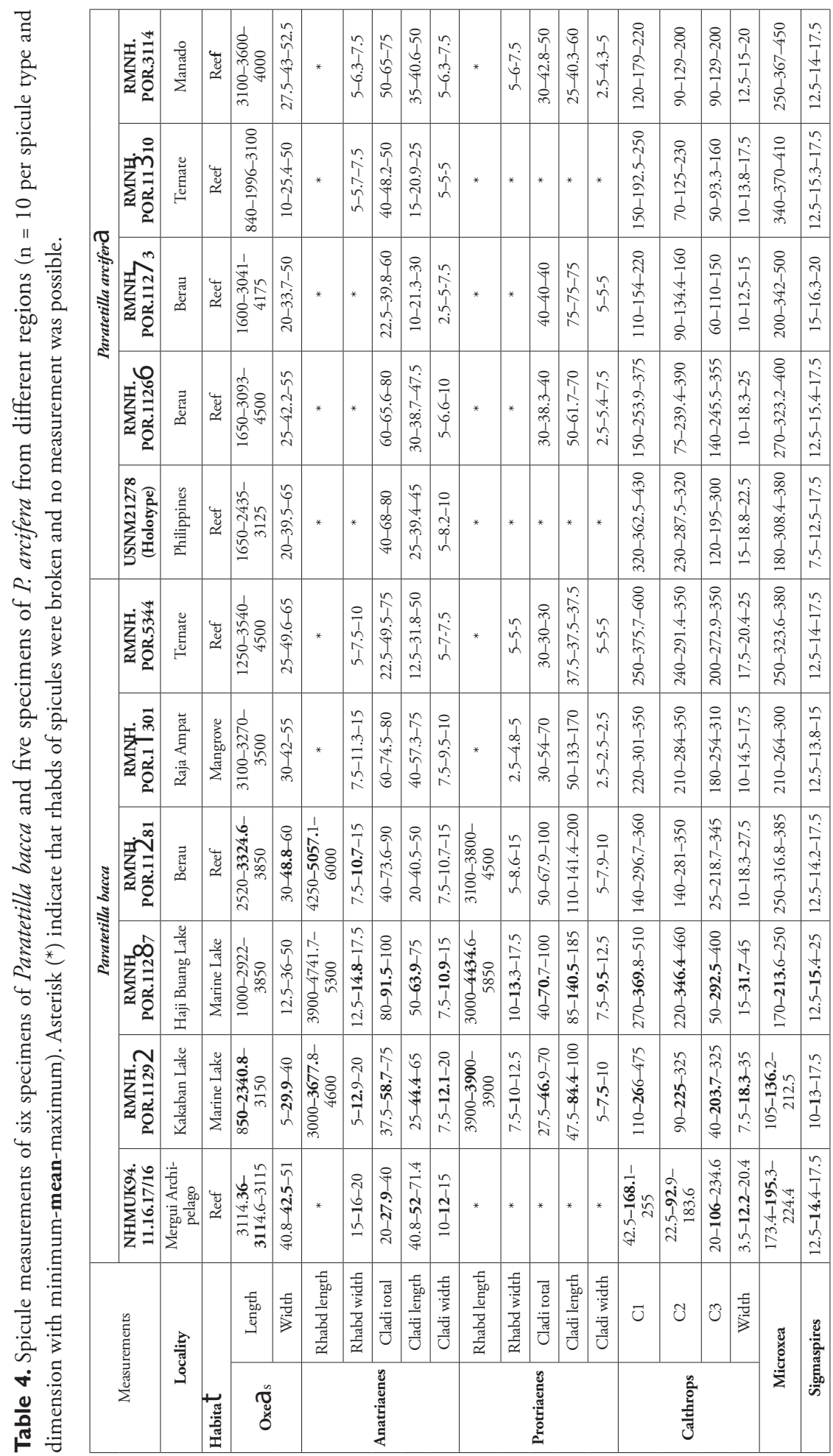




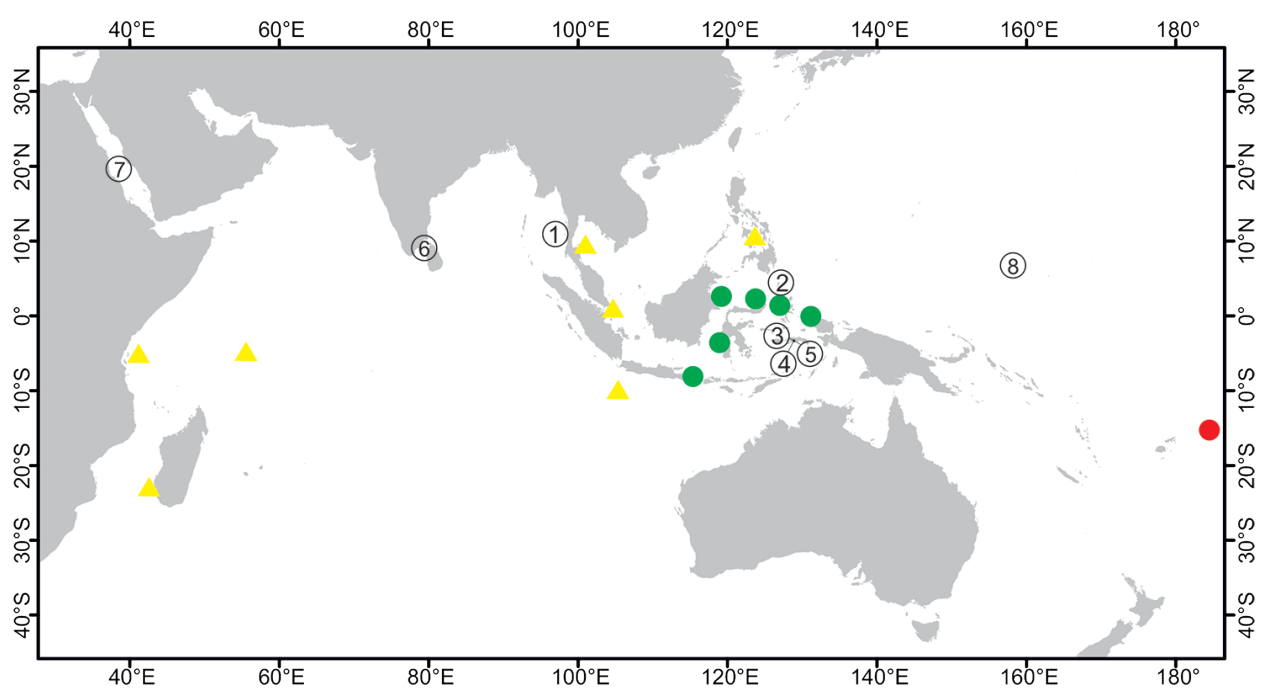

Figure 2. Distribution of Paratetilla bacca. Red dot: type locality, Stelletta bacca Selenka, 1867, American Samoa. Green dots: Indonesian localities where the species was collected recently. Yellow triangles: Records from localities outside Indonesia, Zanzibar, Southwest Madagascar, Seychelles, Thailand, Singapore, Christmas Island, and Philippines. Circled numbers: type localities of synonymized species, I Tethya merguiensis Carter, 1873, Mergui Archipelago 2 Tetilla ternatensis Kieschnick, 1896, Ternate Island 3 Tetilla amboinensis Kieschnick, 1898, Ambon Island 4 Tetilla violacea Kieschnick, 1898, Ambon Island 5 Tetilla rubra Kieschnick, 1898, Ambon Island 6 Paratetilla cineriformis Dendy, 1905, Gulf of Manaar, Sri Lanka. 7 Paratetilla eccentrica Row, 1911, Tella Tella Kabira, Red Sea 8 Paratetilla lipotriaena de Laubenfels, 1954, Matalanim, Eastern Pohnpei, Micronesia.

morphological variability we recommend further molecular studies, particularly of $P$. bacca from its type locality (American Samoa). This would allow a more detailed description of the genetic variation of $P$. bacca and verify our initial taxonomic proposal based on morphology.

\section{Paratetilla arcifera Wilson, 1925}

Figs 3, 4, 5

Paratetilla arcifera Wilson, 1925: 380; plate 40, fig. 2; plate 48, fig. 6 (type seen).

Material examined. Holotype USNM 21278, Albatross Stn. 5400, Malapascua Island, Cebu, Philippines, 46 m, 16 Mar 1909. INDONESIA. East Kalimantan, Berau reef, RMNH.POR.11131, RMNH.POR.11265, RMNH.POR.11266, RMNH. POR.11269, RMNH.POR.11267, RMNH.POR.11268, RMNH.POR.11270, RMNH.POR.11271, RMNH.POR.11272, RMNH.POR.11273. Bali, RMNH. POR.1870. Java, Thousand Islands, RMNH.POR. 2076. Sulawesi, Bunaken, RMNH. 


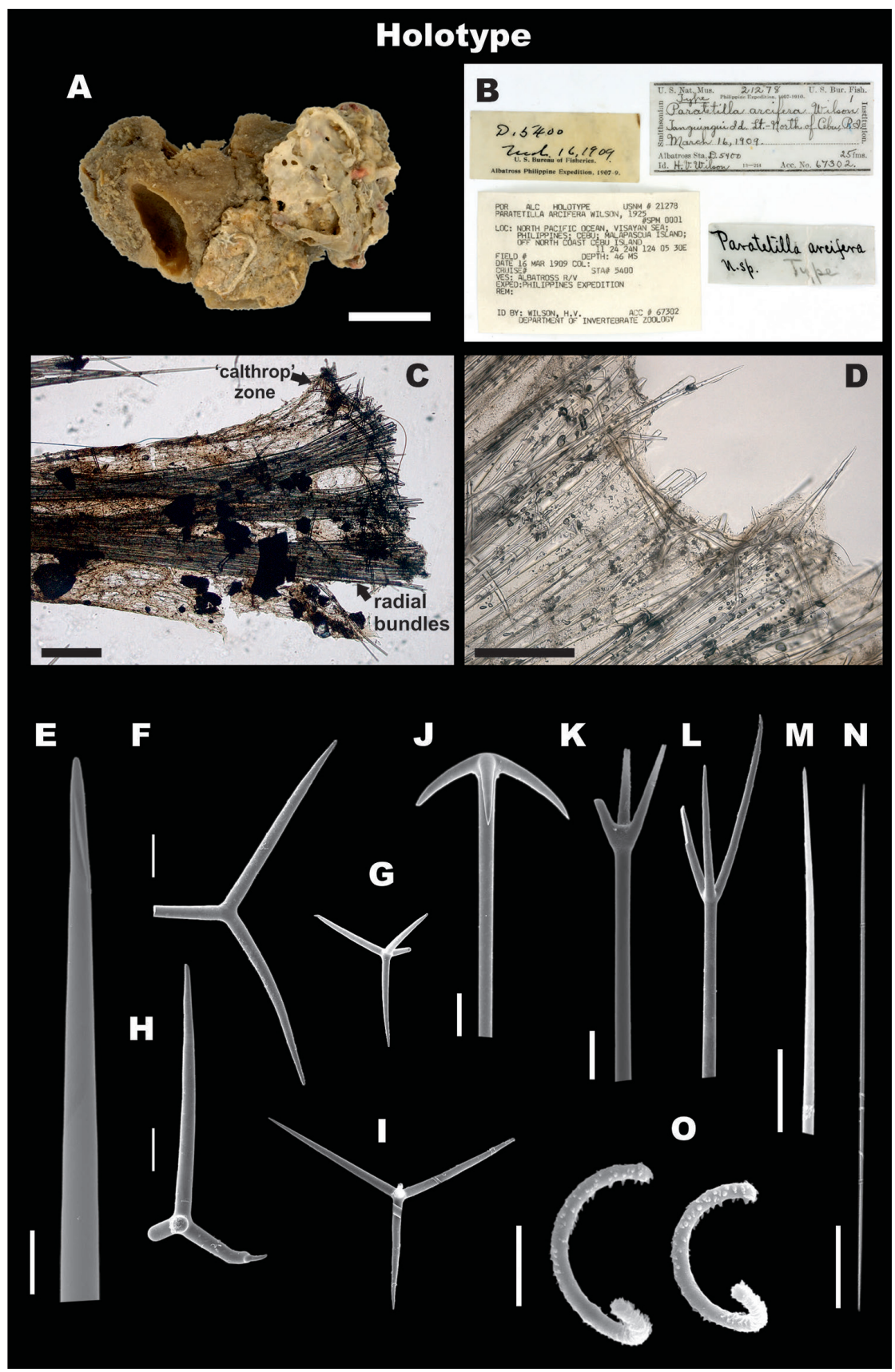

Figure 3. Paratetilla arcifera. Holotype USNM 21278, Malapascua Island, Cebu, Philippines A preserved specimen showing large porocalices B Labels of holotype $\mathbf{C}$ skeleton, showing calthrops and radial bundles $\mathbf{D}$ skeleton, showing oxeas, calthrops, and anatriaenes $\mathbf{E}$ oxea, end detail $\mathbf{F}$-I different calthrop shapes and sizes $\mathbf{J}$ anatriaene $\mathbf{K}$, $\mathbf{L}$ protriaene, different types $\mathbf{M}$ thin microxea, detail $\mathbf{N}$ thin microxea, full length $\mathbf{O}$ sigmaspires. Scale bars: $1 \mathrm{~cm}(\mathbf{A}) ; 500 \mu \mathrm{m}(\mathbf{C}, \mathbf{D}) ; 100 \mu \mathrm{m}(\mathbf{E}) ; 50 \mu \mathrm{m}(\mathbf{F}-\mathbf{I}, \mathbf{N})$; $20 \mu \mathrm{m}(\mathbf{J}) ; 40 \mu \mathrm{m}(\mathbf{K}, \mathbf{L}) ; 5 \mu \mathrm{m}(\mathbf{M}, \mathbf{O})$. 

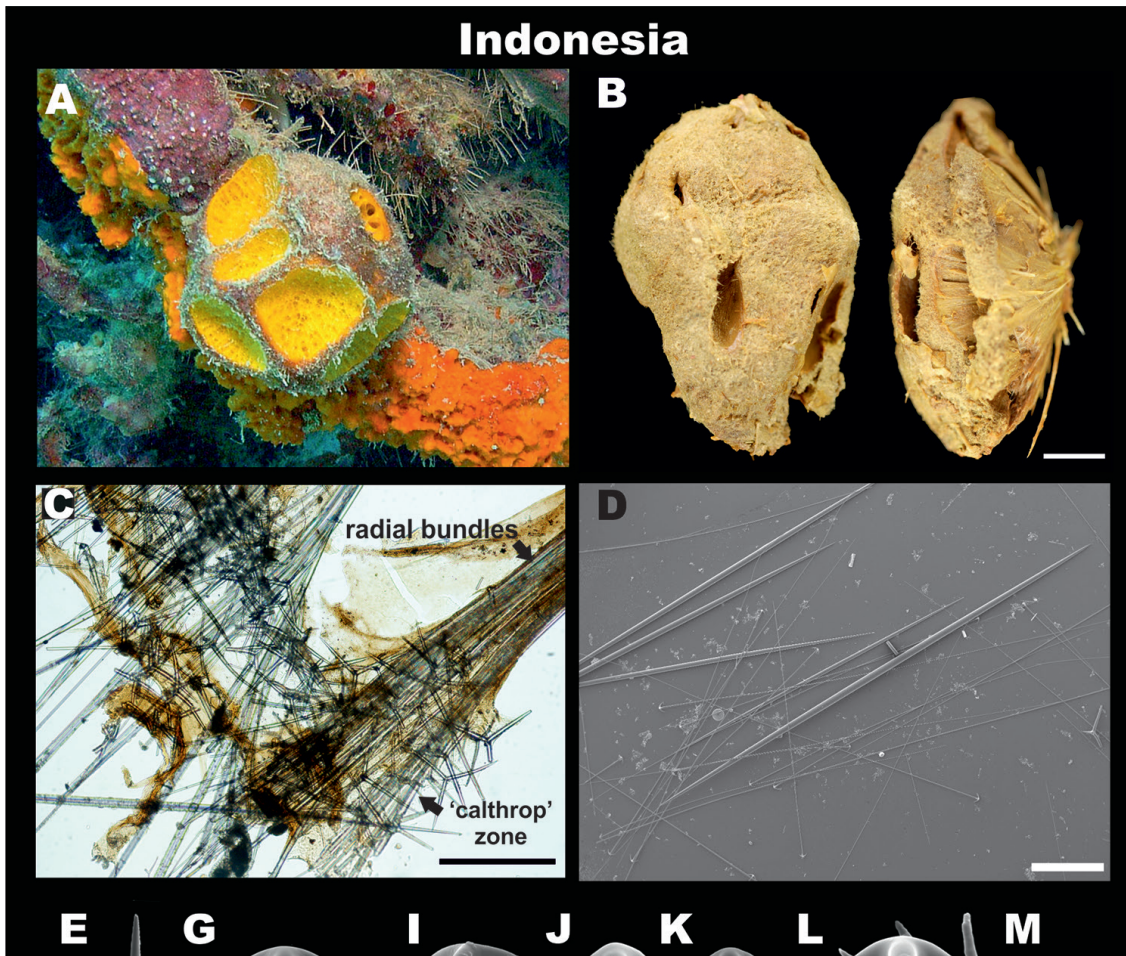

ㄹ.
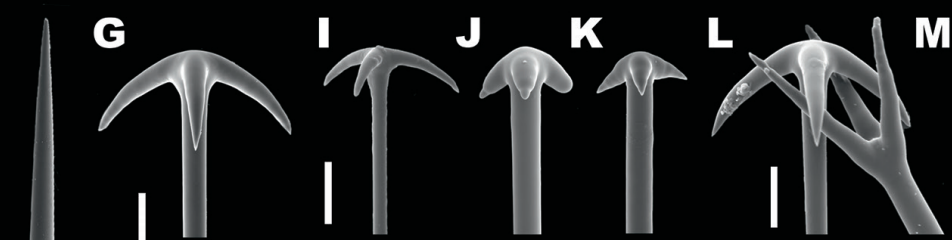

M
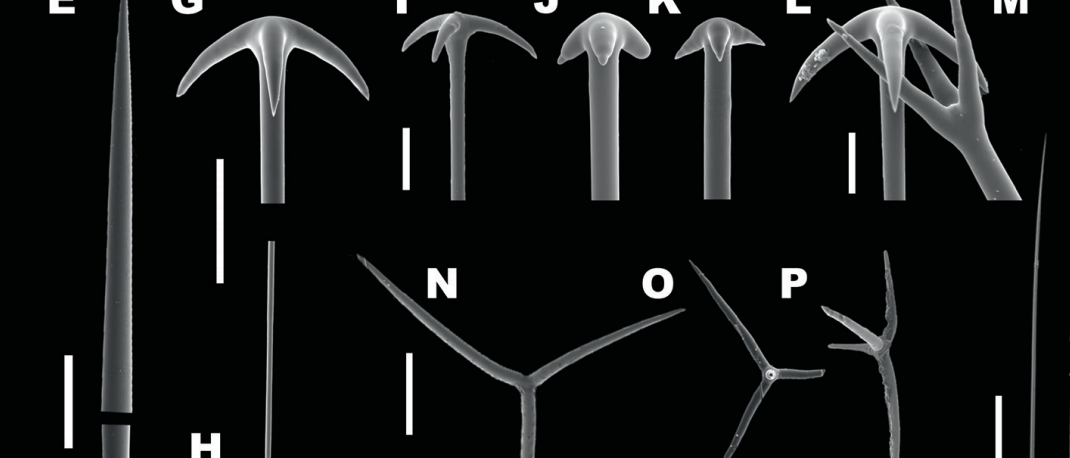
POR.3114; Manado RMNH.POR.3114. Ternate, Ternate reef, RMNH.POR.11310. West Papua, Kerupiar Island reef, RMNH.POR.11280; Outside Ctenophore Lake, RMNH.POR.11275; Gam Island, RMNH.POR.11277, RMNH.POR.11278, RMNH.POR.11279, RMNH.POR.11274, RMNH.POR.11276. TAIWAN. Reef, RMNH.POR.3196, RMNH.POR.3206, RMNH.POR.3225, RMNH.POR.3236.

Description. External morphology. Globular sponges, size from 3 to $6 \mathrm{~cm}$ in diameter (Figs 3A, 4A). Surface hispid due to the projecting spicules, covered by numerous porocalices. Porocalices are bowl-shape, with oval apertures, up to $10 \times 5 \mathrm{~mm}$ and $6 \mathrm{~mm}$ deep, few, mainly on the top surface of the sponge; in preserved material, most porocalices remained open (Figs 3A, 4A). Color generally bright orange when alive, which turns darker or even brown in ethanol. No granules in choanosome. Fleshy consistency.

Skeleton. No cortex. Skeleton composed by bundles of oxeas and triaenes radiating from a central core, and spaced between each other, giving a softer consistency (Figs 3C, D, 4C).

Megascleres. Holotype and Indonesian specimen size ranges are summarized in Table 4. Holotype: Oxeas 1650-2435-4500 $\mu \mathrm{m} \times 20-36.8-65 \mu \mathrm{m}$; anatriaenes very abundant (Figure 3J), rhabds generally broken, up to $6000 \times 10 \mu \mathrm{m}$, apparently tapering to dimensions of $<1 \mu \mathrm{m}$, cladi thin, slightly flattened, 40-68-80 $\mu \mathrm{m}$ $\times 25-39.4-45 \mu \mathrm{m} \times 5-8.2-10 \mu \mathrm{m}$; few protriaenes (Figure $3 \mathrm{~K}, \mathrm{~L}$ ), thinner and small cladi $(40-65-80 \mu \mathrm{m} \times 60-85-110 \mu \mathrm{m})$, rhabds mostly broken, up to $5000 \times 15 \mu \mathrm{m}$, tapering to dimensions of $<1 \mu \mathrm{m}$; two types of calthrop-like short shafted triaenes, one type with four rays of which three are short $(150-300 \mu \mathrm{m})$ and one is large $(400 \mu \mathrm{m})$ (Figure $3 \mathrm{H}$ ), the other type has three rays of almost equal length up to $400 \mu \mathrm{m}$ (Figure 3 F-G, I); calthrops are abundant in some specimens, but can be in very low numbers till almost absent in some others, they are located immediately below the surface, constituting a thin layer that can be missed in some spicule preparations.

Microscleres. Thin microxeas are common, 180-308.4-380 $\mu \mathrm{m}$, 'hair-like' (Figs 3M, N, 4R, S). Sigmaspires, 7.5-12.5-17.5 $\mu \mathrm{m}$, C-S shape (Figs 3O, 4T).

Ecology. Coral reef habitats at depths from 1- 20/30 m. Absent from marine lakes, mangroves and other localities with higher sedimentation and/or variable salinity.

Distribution. Occur in coral reefs of Berau, Bunaken, Ternate, and Raja Ampat. An additional record from its type locality, Philippines (Wilson, 1925) could be inferred from the literature (see Longakit et al. 2005: Figure 9 as P. bacca), and collections from Taiwan (Figure 5).

Remarks. Spicule sizes for most Indonesian specimens vary within the holotype ranges, except for the Ternate population, which exhibits smaller sizes and lack of protriaenes (Table 4). The typical orange color and 'fleshy' soft consistency are easy distinctive characters of this species (Figure 4A). The differences between $P$. arcifera and its congener $P$. bacca lie in the stark orange coloring, the fleshy consistency, the lack of granules, the larger porocalices, and thin microxeas generally longer than in $P$. bacca. $P$. arcifera specimens are typically larger than $P$. bacca. We, furthermore, deem $P$. arcifera a distinct species from $P$. bacca, based on recent molecular phylogenetic analyses that included $P$. arcifera (genbank accession number LT628349) and P. bacca (LT628350) specimens reviewed in our current study and support the hypothesis of two species (Schuster et al. 2017). 


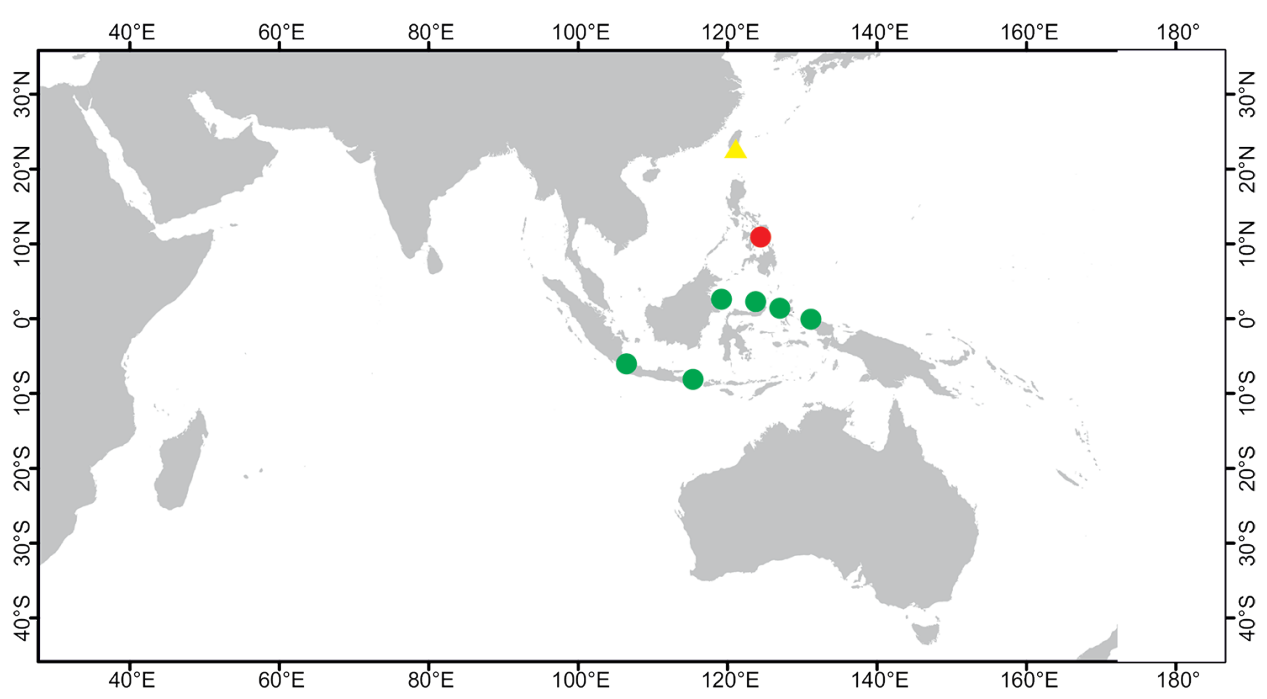

Figure 5. Distribution of Paratetilla arcifera. Red dot: type locality, Paratetilla arcifera Wilson, 1925, Tanguingui Island, Philippines. Green dots: Indonesian localities where the species was collected recently. Yellow triangle: Records from localities outside Indonesia, Taiwan.

\section{Genus Cinachyrella Wilson, 1925}

Currently, 42 species are valid within the genus Cinachyrella according to the WPD (van Soest et al. 2018), including the homonyms of C. globulosa and one additional description of C. cavernosa (Lamarck, 1815) sensu Burton (1959). Originally, Wilson (1925) grouped certain species of the genera Tetilla and Cinachyra under the subgenus Cinachyrella based on the presence of porocalices (poriferous pits) and the absence of cortex. Subsequently, a complete review of Caribbean species by Rützler and Smith (1992) included four valid Cinachyrella species and it was recently complemented with the description of two new species from Brazilian deep waters (Fernández et al. 2018). The most recent review of the Indo-Pacific species was attempted by Burton (1934). In his monograph, Burton established that 16 nominal species were synonyms of the widespread and variable species Cinachyrella australiensis (Carter, 1886) (see Table 5). However, the validity of Burton's conclusion was not accepted by van Soest and Rützler (2002) in the Systema Porifera. Therefore, a further examination of the junior synonyms proposed by Burton (1934) was needed and became one of the principal aims that guide this revision. A general review of the historic events about species descriptions and synonyms is provided in Table 5. Emphasis was given to species described based on Indo-Pacific specimens. Remarks were added to clarify the early confusion introduced by Lindgren (1898) when he identified some Cinachyrella specimens as Tetilla ternatensis (=Paratetilla bacca), although his specimens have conspicuos acanthose microxea and lack of calthrop-like spicules, misleading later descriptions for both genera.

Cinachyrella australiensis has been recorded from a wide geographic area from the Gulf of Oman (van Soest and Beglinger 2008), Thailand (Kritsanapuntu et al. 2001ab, Putchakarn 2007), Vietnam (Azzini et al. 2007), Singapore (Lim et al. 2008), North 
Australia (McDonald et al. 2002), the Great Barrier Reef in Australia (Burton 1934), Southeast Australia (Carter, 1886), and Indonesia (e.g. Becking et al. 2006, de Voogd and Cleary 2008, de Voogd et al. 2009, Becking et al. 2013), inhabiting coastal mangroves, reefs, and marine lakes.

Ecological studies on the morphological plasticity of $C$. australiensis from North Australia (McDonald et al. 2002) and Thailand (Kritsanapuntu et al. 2001) have concluded that this species can adapt to extreme sedimentation and water current regimes through the variation of the body shape and reinforcement of spicules. Although these surveys showed interesting data on the individual sizes, porocalices, silica/organic content, both of them lack robust taxonomic data (type of spicules and their dimensions). It is therefore unclear whether the observed plasticity can be attributed to natural variation within the same species or may possibly be explained by different species inhabiting different habitats.

Table 5. Historic milestones in the taxonomy of Cinachyrella australiensis and other Cinachyrella species from Indonesia. Asterisk $\left(^{*}\right)$ indicates misidentification of Cinachyrella specimens as Paratetilla.

\begin{tabular}{|c|c|c|}
\hline Year & Author & Descriptions / StatementS \\
\hline 1873 & Gray & $\begin{array}{l}\text { Description of the monotypic genera Psetalia and Labaria, with the species P. globulosa and } \\
\text { L. hemisphaerica, respectively. }\end{array}$ \\
\hline 1886 & Carter & $\begin{array}{l}\text { Description of Tethya cranium var. australiensis from Port Phillip Heads (South Australia) } \\
\text { collected at } 36 \text { m depth. This species was characterized by the presence of minutely spined } \\
\text { (= acanthose) microxea }(210 \mu \mathrm{m}) \text {. }\end{array}$ \\
\hline 1888 & Sollas & $\begin{array}{l}\text { Establishment of Family Tetillidae. Tethya cranium var. australiensis was redescribed as Tetilla } \\
\text { (?) australiensis. In addition, Sollas noted that the characteristic microxeas of T. australiensis } \\
\text { were also present in T. merguiensis as well, but were more abundant in T. australiensis. }\end{array}$ \\
\hline 1888 & Lendenfeld & $\begin{array}{l}\text { Description of genus Spiretta within Family Tetillidae, including two new species } S \text {. } \\
\text { raphidiophora and } S \text {. porosa, from Port Jackson (SE Australia) and Port Denison (NE } \\
\text { Australia), respectively. The former with microxea }(240 \times 2 \mu \mathrm{m}) \text { and the latter without them. }\end{array}$ \\
\hline 1891 & Keller & $\begin{array}{l}\text { Description of Cinachyra schulzei from the Red Sea and Mozambique, with microxea } 250 \times \\
5 \mu \mathrm{m} \text {. }\end{array}$ \\
\hline $1896^{*}$ & Kieschnick & $\begin{array}{l}\text { Description of Tetilla ternatensis based on material from Ternate Island (Indonesia). He } \\
\text { mentioned "Vierstrahler" (= calthrops). }\end{array}$ \\
\hline $1898^{*}$ & Lindgren & $\begin{array}{l}\text { Redescription of Tetilla ternatensis based on Java material. It is remarkable that he } \\
\text { mentioned the presence of numerous microxea }(240 \times 4 \mu \mathrm{m}) \text { and sigmaspires } 24 \mu \mathrm{m} \text {. }\end{array}$ \\
\hline 1898 & Kieschnick & $\begin{array}{l}\text { Description of Tetilla schulzei from material of NE Australia to Ambon Island, with } \\
\text { microxea (198-220 } \mu \mathrm{m} \times 4 \mu \mathrm{m}) \text {. T. schulzei has 'oscula' that we interpret as porocalices. } \\
\text { Although Kieschnick entitled T. schulzei as new species, it is not clear if he was aware of } \\
\text { Cinachyra schulzei described by Keller (1891). Three other Tetilla species with "Vierstrahler" } \\
\text { (= calthrops) spicules were described (see Table 3). }\end{array}$ \\
\hline 1899 & Thiele & $\begin{array}{l}\text { Record of Tetilla australiensis from Sulawesi (Indonesia). Specimens with acanthose microxea } \\
(180-200 \mu \mathrm{m} \times 2.5 \mu \mathrm{m}) \text {. }\end{array}$ \\
\hline $1900^{*}$ & Thiele & $\begin{array}{l}\text { With the redescription of Tetilla ternatensis Kieschnick, 1896, Thiele noticed the } \\
\text { misidentification of T. ternatensis by Lindgren (1898) and pointed out that Lindgren } \\
\text { specimens exhibited microxea resembling Tetilla australiensis (Carter, 1886). }\end{array}$ \\
\hline 1900 & Kieschnick & $\begin{array}{l}\text { Additional record of Tetilla schulzei from Ambon Islands, including description of the } \\
\text { specimens, with microxea from } 198 \text { to } 220 \mu \mathrm{m} \times 4 \mu \mathrm{m} \text {. }\end{array}$ \\
\hline $1900^{*}$ & Kirkpatrick & $\begin{array}{l}\text { Extension of geographical range of T. bacca and T. ternatensis to Christmas Island. T. } \\
\text { bacca specimens were described with identical spicules to Lindgren's material from Java. T. } \\
\text { ternatensis also similar to Lindgren's material of T. ternatensis, this is having microxeas and } \\
\text { missing calthrops. }\end{array}$ \\
\hline 1902 & Sollas & $\begin{array}{l}\text { Description of Cinachyra malaccensis from Malaysia. Cup-shaped porocalices are described } \\
\text { together with different spicules, except for microxea. In the available figures, no microxeas } \\
\text { are shown. }\end{array}$ \\
\hline
\end{tabular}




\begin{tabular}{|c|c|c|}
\hline Year & Author & Descriptions / StatementS \\
\hline $1903^{*}$ & Thiele & $\begin{array}{l}\text { Redescription of Tetilla ternatensis Kieschnick, 1898. He drew attention on the } \\
\text { misidentification of T. ternatensis by Lindgren (1898), clarifying that Lindgren specimens } \\
\text { exhibited microxea resembling Tetilla australiensis (Carter, 1886). }\end{array}$ \\
\hline $1903^{*}$ & Lendenfeld & $\begin{array}{l}\text { Designation of a new species Tetilla lindgreni based on T. ternatensis material described } \\
\text { by Lindgren (1898) and Kirkpatrick (1900), excluding the original description of } \\
\text { Kieschnick (1896), because the latter one has calthrop-like spicules. Two Spiretta species, } S \text {. } \\
\text { raphidiophora and S. porosa, transferred to genus Tetilla. }\end{array}$ \\
\hline 1905 & Dendy & $\begin{array}{l}\text { Monograph on sponges from Sri Lanka. Description of Tetilla anomala, showing remarkable } \\
\text { siliceous micro-spherules }(4 \mu \mathrm{m}) \text { and no microxeas. Description of Tetilla poculifera with } \\
\text { smooth microxeas }(230 \times 5 \mu \mathrm{m}) \text {. Description of Tetilla limicola, pink-color and root tuft; } \\
\text { neither porocalices nor microxea are described. The genus Paratetilla was established. }\end{array}$ \\
\hline 1906 & Baer & $\begin{array}{l}\text { Description of Tethya armata from Zanzibar (Africa, Indian Ocean). It is characterized by a } \\
\text { dermal cortex formed by microxea }(166-296 \mu \mathrm{m} \times 1-2 \mu \mathrm{m}) \text {. }\end{array}$ \\
\hline 1907 & Lendenfeld & $\begin{array}{l}\text { Description of Cinachyra isis and Tethya hebes from NW Australia, the first one exhibiting } \\
\text { smaller microxea }(130-160 \mu \mathrm{m} \times 2-5.5 \mu \mathrm{m}) \text {, and the second one larger rough microxea }(= \\
\text { acanthose microxea, } 250-275 \mu \mathrm{m} \times 4-6 \mu \mathrm{m}) \text {. Description of Cinachyra alba-tridens, C. alba- } \\
\text { obtusa, and C. alba-bidens species, slightly differentiated by the geometry and abundance } \\
\text { of triaenes. He kept the three species because they were collected in three distant localities, } \\
\text { Chagos Archipelago, Papua New Guinea, and Tonga Islands, respectively; "alba-group" } \\
\text { species do not contain microxeas, and sigmaspires are small }(<10 \mu \mathrm{m}) \text {. }\end{array}$ \\
\hline 1911 & Row & $\begin{array}{l}\text { Description of Chrotella ibis from the Red Sea. Species with smooth microxea }(150 \times 2.1 \\
\mu \mathrm{m}) \text {, sharing this character with Tetilla poculifera, and Paratetilla species } P \text {. merguiensis, } P \text {. } \\
\text { eccentrica and } P \text {. cineriformis. In his description, Row clearly differentiated his species from } \\
\text { T. australiensis due to the latter having acanthose microxea. }\end{array}$ \\
\hline 1911 & Hentschel & $\begin{array}{l}\text { Description of Tetilla cinachyroides from South Australia. Species with acanthose microxea } \\
(112-168 \mu \mathrm{m} \times 2.5 \mu \mathrm{m}) \text {, sigmaspires }(10-12 \mu \mathrm{m}) \text { and spherules }(5 \mu \mathrm{m}) \text {. }\end{array}$ \\
\hline 1912 & Hentschel & $\begin{array}{l}\text { Description of Cinachyra mertoni and Cinachyra nuda from Aru- and Kei- Islands } \\
\text { (Indonesia). Both species contain microxea, the first one smooth } 250 \mu \mathrm{m} \text {, whereas in the } \\
\text { second one they are acanthose, from } 200-280 \mu \mathrm{m} \text {, and no anatriaenes were found. A third } \\
\text { species, Tethya clavigera, with oscula (similar to porocalices) and no microxea was also } \\
\text { described. }\end{array}$ \\
\hline 1922 & Dendy & $\begin{array}{l}\text { Description of Cinachyra vaccinata and C. providentiae from the Indian Ocean. Both of } \\
\text { them with microxea (no mention whether acanthose or not), being } 200 \times 4 \mu \mathrm{m} \text { in the } \\
\text { former, and } 220 \times 5.5 \mu \mathrm{m} \text { in the latter one. C. vaccinata characterized by small hair-like } \\
\text { protri- and prodiaenes, terminating in an elongated oval swelling tip unique to this species. } \\
\text { C. providentiae with bottle-shaped porocalices. }\end{array}$ \\
\hline 1925 & Wilson & $\begin{array}{l}\text { Establishment of Cinachyrella as a subgenus of Tetilla, with type species Tetilla hirsuta } \\
\text { Dendy, } 1889 \text {. The characters used to distinguish Cinachyrella species from the other were } \\
\text { special depressions (=porocalices) and no specialization of a cortical zone. Wilson included } \\
\text { the following species within Cinachyrella: Cinachyra malaccensis Sollas, 1902; Tetilla } \\
\text { limicola Dendy, 1905; Tetilla anomala Dendy, 1905; Cinachyra isis Lendenfeld, 1907; C. } \\
\text { hamata Lendenfeld, 1907; C. alba-tridens Lendenfeld, 1907; C. alba-bidens Lendenfeld, } \\
\text { 1907; C. alba-obtusa Lendenfeld, 1907; C. vertex Lendenfeld, 1907; Tetilla cinachyroides } \\
\text { Hentschel, 1911; Cinachyra phacoides Hentschel, 1911; Tethya clavigera Hentschel, 1912; } \\
\text { Cinachyra mertoni Hentschel, 1912; Cinachyra nuda Hentschel, 1912; Cinachyra vaccinata } \\
\text { Dendy, 1922; Cinachyra providentiae Dendy, 1922. In addition, Cinachyrella crustata and } \\
\text { Cinachyrella paterifera were described from Philippines. C. crustata with distinctive long and } \\
\text { stout promonoenes, no microxea. C. paterifera with a characteristic cloaca (= large osculum) } \\
\text { on top and root-like structure to attach to sediments, microxea }(250 \times 2 \mu \mathrm{m}) \text { observed in } \\
\text { two specimens although almost absent in the third one of the type series, pointing out a } \\
\text { high variability in the presence of microxea within the same individual. }\end{array}$ \\
\hline 1934 & Burton & $\begin{array}{l}\text { Taxonomic revision of Cinachyra australiensis. In his compilation, Burton grouped } 16 \\
\text { nominal species described in } 32 \text { references and designated them as junior synonyms of the } \\
\text { widespread species } C \text {. australiensis. Three different groups were recognized: the australiensis- } \\
\text { group characterized by the presence of acanthose microxea; the schulzei-group with smooth } \\
\text { microxea; and the porosa-group without microxea. Description of genus Raphidotethya. }\end{array}$ \\
\hline 1954 & de Laubenfels & $\begin{array}{l}\text { Identification of Cinachyra porosa and Cinachyra australiensis from Micronesia (West-Central } \\
\text { Pacific). }\end{array}$ \\
\hline
\end{tabular}




\begin{tabular}{|c|c|c|}
\hline Year & Author & Descriptions / StatementS \\
\hline 1973 & Thomas & $\begin{array}{l}\text { Records of Cinachyra cavernosa (Lamarck, } 1815) \text { from the Seychelles Islands, having, } \\
\text { microxea }(126 \times 2 \mu \mathrm{m}) \text { sometimes granulated (= acanthose). Among the junior synonyms } \\
\text { of } C \text {. cavernosa, Thomas included Tethya cranium var. australiensis Carter, 1886, Chrotella } \\
\text { australiensis Burton, 1937, and Chrotella cavernosa Burton, 1959. However, in the WPD } \\
\text { (van Soest et al. 2018) C. cavernosa is still a valid species. }\end{array}$ \\
\hline 1982 & Pulitzer-Finali & $\begin{array}{l}\text { Description of Cinachyra tenuiviolacea from the Great Barrier Reef (Australia), characterized } \\
\text { by a light violet color, small oxeas (up to } 2500 \mu \mathrm{m} \times 13-25 \mu \mathrm{m} \text { ), atrophic anatriaenes, no } \\
\text { microxeas, and no protriaenes in the choanosome. }\end{array}$ \\
\hline 1987 & Rützler & $\begin{array}{l}\text { Review of Family Tetillidae, including seven genera (all except for Fangophilina). Subgenus } \\
\text { Cinachyrella was elevated to the hierarchy of genus. }\end{array}$ \\
\hline 1992 & $\begin{array}{l}\text { Rützler and } \\
\text { Smith }\end{array}$ & $\begin{array}{l}\text { Review of four species of Cinachyrella for the Caribbean region, mainly described by Uliczka } \\
\text { (1929). Geometry and size ranges of all spicule types were shown. According to their } \\
\text { descriptions, Cinachyrella kuekenthali is the most similar species to C. australiensis, since } \\
\text { both of them have acanthose microxea. }\end{array}$ \\
\hline 1994 & $\begin{array}{c}\text { Hooper and } \\
\text { Wiedenmayer }\end{array}$ & $\begin{array}{l}\text { Compilation of Cinachyra australiensis synonyms based on Burton (1934) taxonomic } \\
\text { decision. }\end{array}$ \\
\hline 2002 & $\begin{array}{l}\text { van Soest and } \\
\text { Rützler }\end{array}$ & $\begin{array}{l}\text { Review of the eight genera of tetillids, including Cinachyrella. Cinachyra australiensis was } \\
\text { transferred into the genus Cinachyrella. The authors considered that all junior synonyms } \\
\text { proposed for C. australiensis by Burton (1934) should need further taxonomic revision. } \\
\text { Moreover, the genera [Psetalia] Gray, } 1873 \text { (nomem oblitum), [Labaria] Gray, } 1873 \\
\text { (nomen oblitum) and Raphidotethya Burton, } 1934 \text { were included as synonyms of the genus } \\
\text { Cinachyrella. }\end{array}$ \\
\hline 2018 & $\begin{array}{c}\text { van Soest et al. } \\
\text { (WPD) }\end{array}$ & $\begin{array}{l}\text { Accepted synonyms of Cinachyrella australiensis (Carter, 1886): Tethya australiensis Carter, } \\
\text { 1886; Spiretta porosa Lendenfeld, 1888; Cinachyra malaccensis Sollas, 1902; Tetilla lindgreni } \\
\text { Lendenfeld, 1903; Tethya armata Baer, 1906; Cinachyra isis Lendenfeld, 1907; Tetilla } \\
\text { cinachyroides Hentschel, 1911; and Cinachyra providentiae Dendy, 1922. Valid Cinachyrella } \\
\text { spp. from the Indo-pacific (excluding species only found in the Red Sea) comprise } 6 \text { species }\end{array}$ \\
\hline 2018 & This study & $\begin{array}{l}\text { From our detailed examination of Indonesian material and type material, we conclude that } \\
\text { in Indonesia there are three species: Cinachyrella australiensis (Carter, 1886), Cinachyrella } \\
\text { porosa (Lendenfeld, 1888), and Cinachyrella paterifera Wilson, 1922. Further investigations } \\
\text { will reveal if the five species from the C. schulzei-group can be synonymized or belong to } \\
\text { separate and distinctive species. }\end{array}$ \\
\hline
\end{tabular}

\section{Cinachyrella australiensis (Carter, 1886)}

Figs 6, 7

Tethya cranium var. australiensis Carter, 1886: 127 (holotype seen).

Tetilla? australiensis; Sollas, 1888: 43.

Spiretta raphidiophora Lendenfeld, 1888: 43 (type seen).

Tetilla hirsuta Dendy, 1889: 75 (type seen).

Tetilla ternatensis Lindgren, 1898: 329 pl. 17, fig. 14; pl. 19, Fig. 25 a-e, a', b’. Ternate Not Tetilla ternatensis; Kieschnick*, 1896: 527.

Tetilla australiensis; Thiele, 1899: 6, pl.1 fig.1; pl. 5, fig. 1 a-e. Celebes Sea.

Tetilla ternatensis; Kirkpatrick, 1900: 132 (material seen) Not Tetilla ternatensis Kieschnick*, 1896: 527.

Tetilla lindgreni Lendenfeld, 1903: 18.

Tetilla australiensis; Lendenfeld, 1903: 20.

Tethya hebes Lendenfeld, 1907: 98, pl. XVI, figs 19-38. 19`South NW Australia, 91 $\mathrm{m}$ depth (syntype seen).

Cinachyra isis Lendenfeld, 1907: 143, pl. XV, figs 54-58, XVI, figs 1-4. Mermaid

Strasse (NW Australia) (syntype seen); Dendy, 1922: 16, pl. 10, figs 3a-b. 
Tetilla cinachyroides Hentschel, 1911: 281, textfig. 1. NW Australia, Barrow Island. Cinachyra nuda Hentschel, 1912:333, pl. XIII, fig.2; pl. XVIII fig. 13. Aru Island (type seen).

Cinachyra vaccinata Dendy, 1922: 14, pl. 1, fig. 4; pl. 11, figs 1a-l. Diego Garcia, Chagos Island (type seen).

Cinachyra providentiae Dendy, 1922: 18, pl.1, figs 5-5a; pl. 10, figs2a-f. Providence Island (type seen).

Tetilla (Cinachyrella) hirsuta; Wilson, 1925: 365, pl. 39, fig.4.

Cinachyra australiensis; Burton, 1934: 523. In part, not C. australiensis in porosa-group, nor $C$. australiensis in schulzei-group; de Laubenfels, 1954: 241, text-fig. 166.

Cinachyrella anatriaenilla Fernandez, Kelly, Bell, 2017: 83, figs 2-4.

Material examined. Holotype NHMUK 1886.12.15.367, Port Phillip Heads, Southeast Australia (as Tethya cranium var. australiensis). Holotype NHMUK 1886.8.27.634, Port Jackson, Sidney, Australia (as Spiretta raphidiophora Lendenfeld, 1888). NHMUK unreg. type, Gulf of Manaar, Sri Lanka (as Tetilla hirsuta Dendy, 1889). NHMUK 1898.12.20.20 Christmas islands (as Tetilla ternatensis Kirkpatrick, 1900). Holotype NHMUK 1908.9.24.19-21, 19 ${ }^{\circ} 17^{\prime} \mathrm{S} 116^{\circ} \mathrm{E}$, Gazelle Exp., Western Australia, (as Tethya hebes Lendenfeld, 1907). Syntype NHMUK 1908.9.24.74, Mermaid Strait, NW Australia (as Cinachyra isis Lendenfeld, 1907). RMNH unreg. fragment taken from the type (pers. comm. NJ de Voogd) and available in Naturalis collections, Aru Island, Indonesia, as Cinachyra nuda Hentschel, 1912. Holotype NHMUK 1921.11.7.6, Diego Garcia, Chagos Islands (as Cinachyra vaccinata Dendy, 1922). Holotype NHMUK 1921.11.7.8, Providence Island, Seychelles (as Cinachyra providentiae Dendy, 1922). INDONESIA. East Kalimantan, Berau reef, RMNH.POR.11101, RMNH. POR.11102, RMNH.POR.11103, RMNH.POR.11104, RMNH.POR.11105, RMNH.POR.11106, RMNH.POR.11107, RMNH.POR.11108, RMNH. POR.11109, RMNH.POR.11110, RMNH.POR.11111, RMNH.POR11112, RMNH.POR.11113, RMNH.POR.11114, RMNH.POR.11115, RMNH. POR.11116, RMNH.POR.11117, RMNH.POR.11210, RMNH.POR.11124, RMNH.POR.11125, RMNH.POR.11126, RMNH.POR.11127, RMNH. POR.11128, RMNH.POR.11129, RMNH.POR.11130, RMNH.POR.11118, RMNH.POR.11119, RMNH.POR.11120, RMNH.POR.11121, RMNH. POR.11122, RMNH.POR.11123; RMNH.POR.11132; RMNH.POR.11133, RMNH.POR.11134, RMNH.POR.11135, RMNH.POR.11136; Pea Bay, RMNH. POR.11162; Haji Buang Lake, RMNH.POR.11137, RMNH.POR.3511, RMNH. POR.3512, RMNH.POR.3513, RMNH.POR.3516, RMNH.POR.3517; Kakaban Lake, RMNH.POR.11161, RMNH.POR.11138, RMNH.POR.11139, RMNH. POR.11140, RMNH.POR.11141, RMNH.POR.11142, RMNH.POR.11143, RMNH.POR.11144, RMNH.POR.11145, RMNH.POR.11146, RMNH. POR.11147, RMNH.POR.11148, RMNH.POR.11149, RMNH.POR.11150, RMNH.POR.11151, RMNH.POR.11152, RMNH.POR.11153, RMNH. POR.11154, RMNH.POR.11155, RMNH.POR.11156, RMNH.POR.11157, RMNH.POR.11158, RMNH.POR.11159, RMNH.POR.11160. Java, Thousand 
Islands, RMNH.POR.1969. Ternate, Ternate reef, RMNH.POR.11308. Sulawesi, Bunaken, RMNH.POR.3108, RMNH.POR.3112, RMNH.POR.3119, RMNH. POR.3122. West Papua, Sawaundarek Lake, RMNH.POR.11163, RMNH. POR.11164, RMNH.POR.11165, RMNH.POR.11166, RMNH.POR.11167; Gam Island, Wallace Lake, RMNH.POR.11168, RMNH.POR.11169 Outside Wallace Lake, RMNH.POR.11170, RMNH.POR.11171, RMNH.POR.11172, RMNH. POR.11173; Gam Island, Blue Water Mangrove, RMNH.POR.11174, RMNH. POR.11175, RMNH.POR.11176, RMNH.POR.11177, RMNH.POR.11178, RMNH.POR.11179, RMNH.POR.11180, RMNH.POR.11181, RMNH. POR.11182, RMNH.POR.11183, RMNH.POR.11184, RMNH.POR.11185, RMNH.POR.11186, RMNH.POR.11187, RMNH.POR.11188, RMNH. POR.11189, RMNH.POR.11190, RMNH.POR.11191， RMNH.POR.11192; Ctenophore Lake, RMNH.POR.11193, RMNH.POR.11194, RMNH.POR.11195, RMNH.POR.11196, RMNH.POR.11197; Outside Ctenophore Lake, RMNH. POR.11198, RMNH.POR.11199, RMNH.POR.11200, RMNH.POR.11201; Big Caulerpa Lake, RMNH.POR.11202, RMNH.POR.11203; Outside Big Caulerpa lake, RMNH.POR.11204; Gam Island, RMNH.POR.11205, RMNH.POR.11206.

Other material: Singapore, RMNH.POR.3520, RMNH.POR.2440, RMNH. POR. 2505.

Other types and material examined (not included as synonyms of $C$. australiensis): NHMUK 1892.8.8.8. Macclesfield Bank, South China Sea Cinachyra schulzei (unpublished material). Holotype NHMUK 1908.9.24.75 Red Sea, Cinachyra trochiformis Keller, 1891. Holotype NHMUK 1907.2.1.14, Gulf of Manaar, Sri Lanka, Tetilla poculifera Dendy, 1905. Holotype NHMUK 1912.2.1.35, Tella Tella Kebira, Red Sea, Chrotella ibis Row, 1911. RMNH unreg. fragment taken from the type (pers. comm. NJ de Voogd) available in Naturalis collections, Kei Island, Indonesia, Cinachyra mertoni Hentschel, 1912.

Description. External morphology. Globular sponges, size from 4 to $10 \mathrm{~cm}$ in diameter (Figure 6A, B). Surface hispid due to the projecting spicules; covered by numerous porocalices. Porocalices are abundant bowl-shape with open oval apertures, up to $10 \times 5 \mathrm{~mm}$ and $5 \mathrm{~mm}$ deep, or bottle-shape, up to $18 \times 6.5 \mathrm{~mm}$, with minuscule apertures (2-3 mm diameter), size of porocalices can vary between habitats; a cloaca, defined as a central exhalant cavity (Boury-Esnault and Rützler, 1997), is distinguishable at the top of some specimens (Figure 6A); in preserved material some porocalices are open. Color generally bright yellow when alive, which turns paler or even white in ethanol. In the field, the sponge can appear brownish due to sediment or greenish due to association with algae.

Skeleton. No cortex. Skeleton composed by bundles of oxeas and triaenes radiating from a central core.

Megascleres. Holotype and Indonesian specimens' measurements are shown in Table 6. Holotype, oxeas 3375-4135.5-5500 $\mu \mathrm{m} \times 15-24.7-37.5 \mu \mathrm{m}$ (Figure 6D, K); no triaenes were observed in the type specimen; in Carter's description, protriaenes are described (135 $\mu \mathrm{m}$ long) and the absence of anatriaenes was explained as their heads 


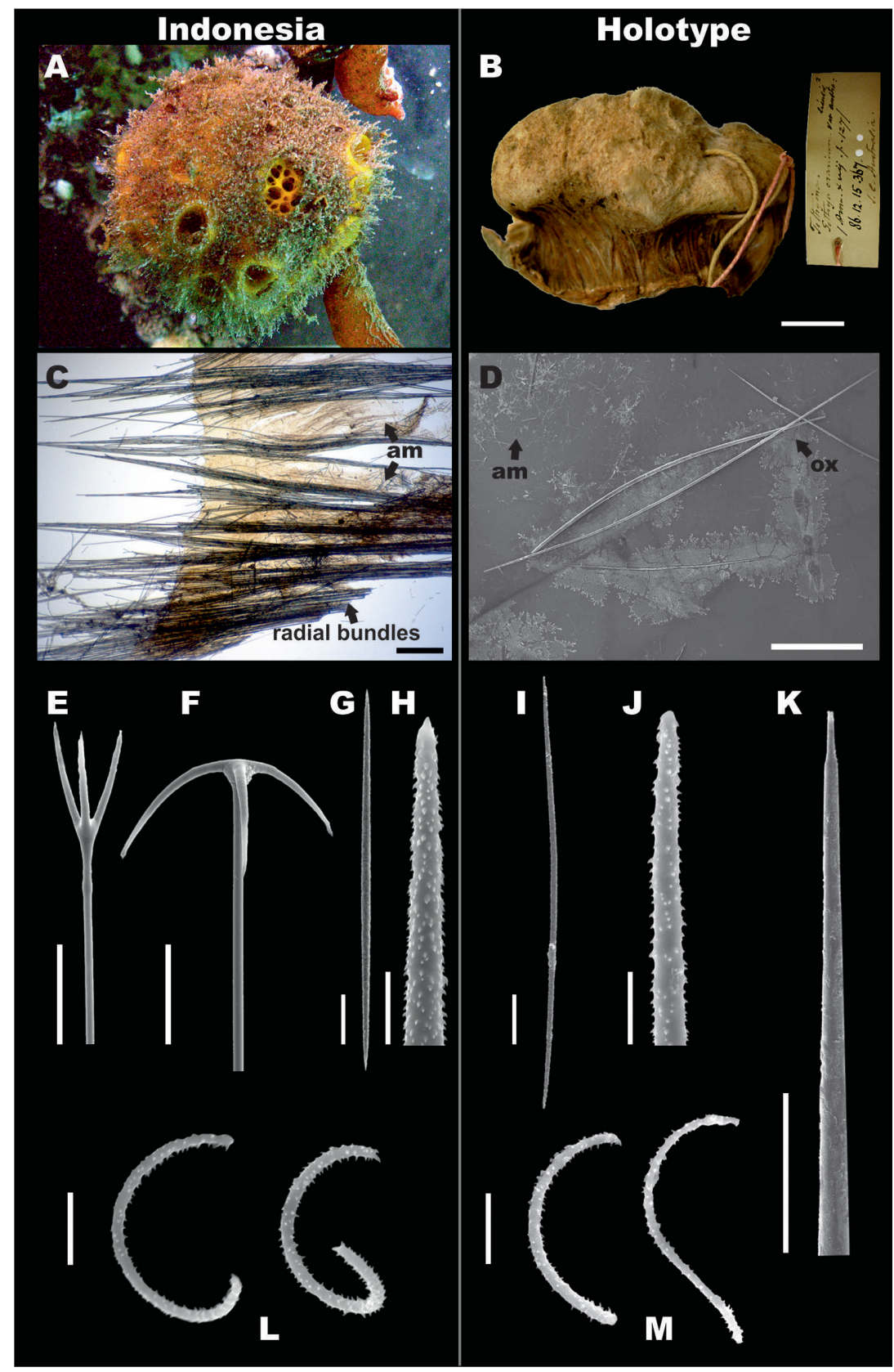

Figure 6. Cinachyrella australiensis. A, C, E-H, L RMNH.POR.11139, Kakaban lake, Indonesia (left side) B, D, I-K, M holotype NHMUK 1886.12.15.367, Port Phillip Heads, Australia (right side) A In situ photograph showing porocalices $\mathbf{B}$ dry specimen, lateral view $\mathbf{C}$ skeleton showing acanthose microxeas $(\mathrm{am})$ and radial bundles with oxeas $\mathbf{D}$ spicule montage showing acanthose microxeas $(\mathrm{am})$, and oxeas (ox) E protriaene $\mathbf{F}$ anatriaene $\mathbf{G}$ Acanthose microxea, full lenght $\mathbf{H}$ acanthose microxea, detail $\mathbf{I}$ acanthose microxea, full length $\mathbf{J}$ acanthose microxea, detail $\mathbf{K}$ oxea, end detail $\mathbf{L}, \mathbf{M}$ sigmaspires. Scale bars: 1 $\mathrm{cm}(\mathbf{B}) ; 500 \mu \mathrm{m}(\mathbf{C}, \mathbf{D}) ; 20 \mu \mathrm{m}(\mathbf{E}-\mathbf{G}, \mathbf{I}) ; 5 \mu \mathrm{m}(\mathbf{H}, \mathbf{J}, \mathbf{L}, \mathbf{M}) ; 50 \mu \mathrm{m}(\mathbf{K})$. 


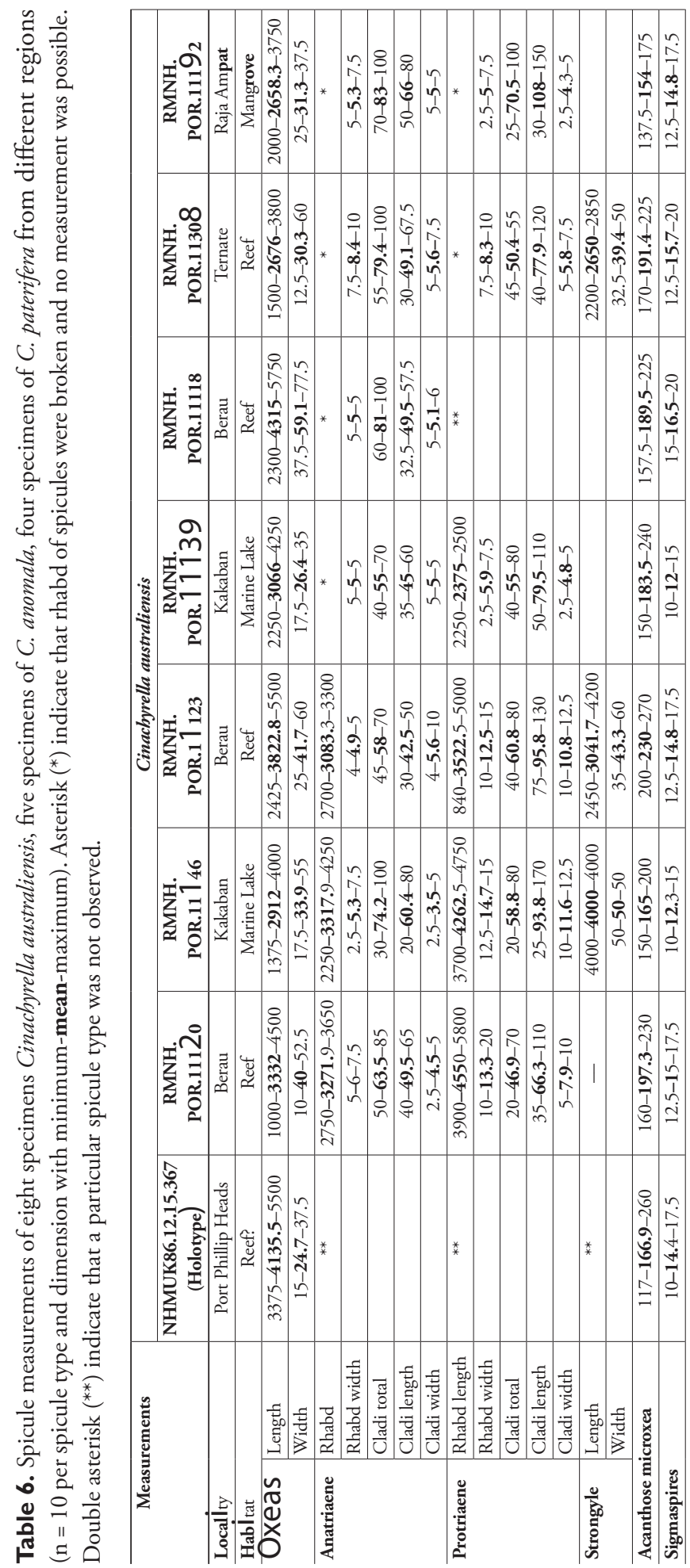




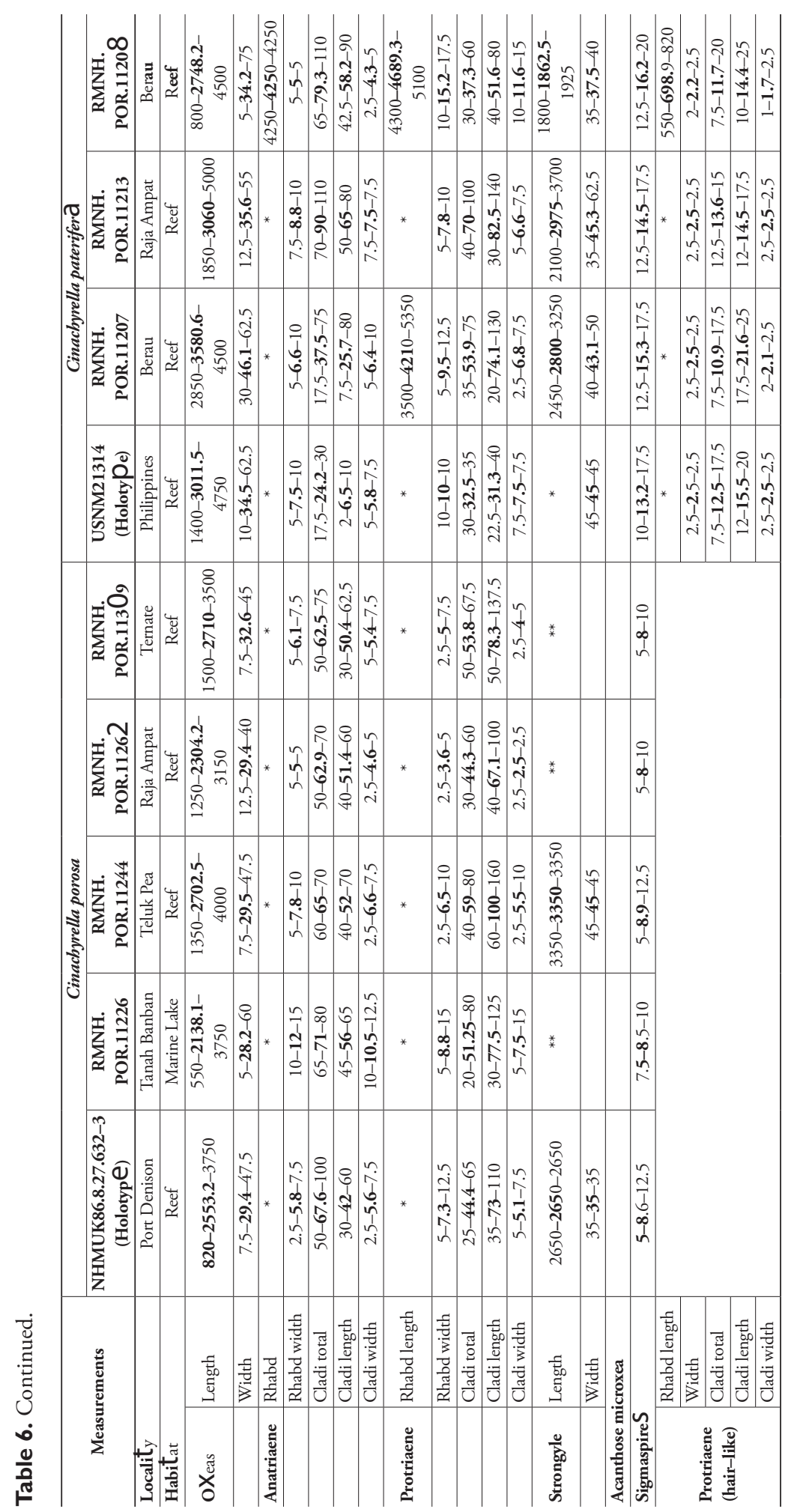


broke off when collected; Indonesian specimens have a wide size range of oxea 1000$5500 \mu \mathrm{m}$ (Figure 6C), abundant anatriaenes (Figure 6F), with rhabd 2250-3224.4$4250 \mu \mathrm{m} \times 2.5-5.7-10 \mu \mathrm{m}$, cladi thin, mainly with obtuse angles 30-70.6-100 $\mu \mathrm{m} \times$ 20-51.7-80 $\mu \mathrm{m} \times 2.5-4.9-10 \mu \mathrm{m}$; protriaenes (Figure 6E), with thin and long cladi $(20-57.1-80 \mu \mathrm{m} \times 25-86.9-170 \mu \mathrm{m} \times 2.5-7.5-12.5 \mu \mathrm{m})$, rhabd up to $5800 \times 20$ $\mu \mathrm{m}$, tapering to dimensions of $<1 \mu \mathrm{m}$; few prodiaenes also observed, having smaller cladi $(20-30 \mu \mathrm{m} \times 20-30 \mu \mathrm{m})$; no calthrop-like triaenes.

Microscleres. Numerous acanthose microxeas, holotype, 117-166.9-260 $\mu \mathrm{m}$ (Figure 6I, J), slightly larger in the Indonesian material 137.5-184.7-270 $\mu \mathrm{m}$ (Figure $6 \mathrm{G}, \mathrm{H})$; sigmaspires vary within the same range in both, holotype and Indonesian specimens, 10-14.4-20 $\mu \mathrm{m}$, C-S shape (Figure 6L, M).

Ecology. Cinachyrella australiensis occurs in reefs, mangroves, and marine lakes, ranging in depths from 0 to at least $30 \mathrm{~m}$, possibly deeper. Specimens can be covered by sand and mud; or in symbiosis with algae, resulting in green external color. This species produces $1-2 \mathrm{~mm}$ sized buds (Figure 8 ) and buds are extensively observed in specimens collected from marine lake habitats.

Distribution. Cinachyrella australiensis has a wide distribution in Indonesia, including Berau, Bunaken, Raja Ampat, Ternate, and Java. Previous Indonesian records are from Spermonde Archipelago in Sulawesi (de Voogd and Cleary 2005, Becking et al. 2006, de Voogd et al. 2006), North Sulawesi (Calcinai et al. 2017), Berau (de Voogd et al. 2009, Becking et al. 2013), Thousand Islands in Java (de Voogd and Cleary 2008), and Raja Ampat (Becking 2008). In addition, this species has also been found in Gulf of Oman (van Soest and Beglinger 2008), Seychelles Islands (Thomas 1973) Southwest Madagascar (Vacelet et al. 1976), Zanzibar (Pulitzer-Finali 1993), Thailand (Kritsanapuntu et al. 2001a-b, Putchakarn 2007), Singapore (Lim et al. 2008), Vietnam (Azzini et al. 2007), Philippines (Longakit et al. 2005), Northern Territory of Australia (McDonald et al. 2002), and the Great Barrier Reef in Australia (Burton 1934).

Remarks. In the type description of $C$. australiensis Carter (1886), the author did not observe anatriaenes as it can be interpreted from his statement: "I saw no anchors (smaller tetractinellids with recurved arms); but as their heads when exposed are generally broken off (for they catch in everything that they touch), it does not follow that they do not form part of the spiculation, particularly as they are present in most of the other species that I have been described (sic)". We examined the holotype kept at the Natural History Museum (NHMUK 1886.12.15.367) and found neither anatriaenes nor protriaenes. In addition, most of the oxeas were broken in the type specimen. Within all the examined material there is a high variability in the presence or absence of triaenes without a distinct geographic pattern. This variation may be related to where the sponge was cut, as it seems that triaenes are particularly abundant around the porocalices compared to other parts of the sponge. These fragile spicules are also easily broken off. We still assign our specimens to the species $C$. australiensis due to the characteristic presence of acanthose microscleres. It is furthermore one of the most common names used in the literature since its description and without further evidence we do not want to cause more confusion. Further examination of Cinachyrella specimens from Australia, in particular from the type locality of $C$. australiensis, will 


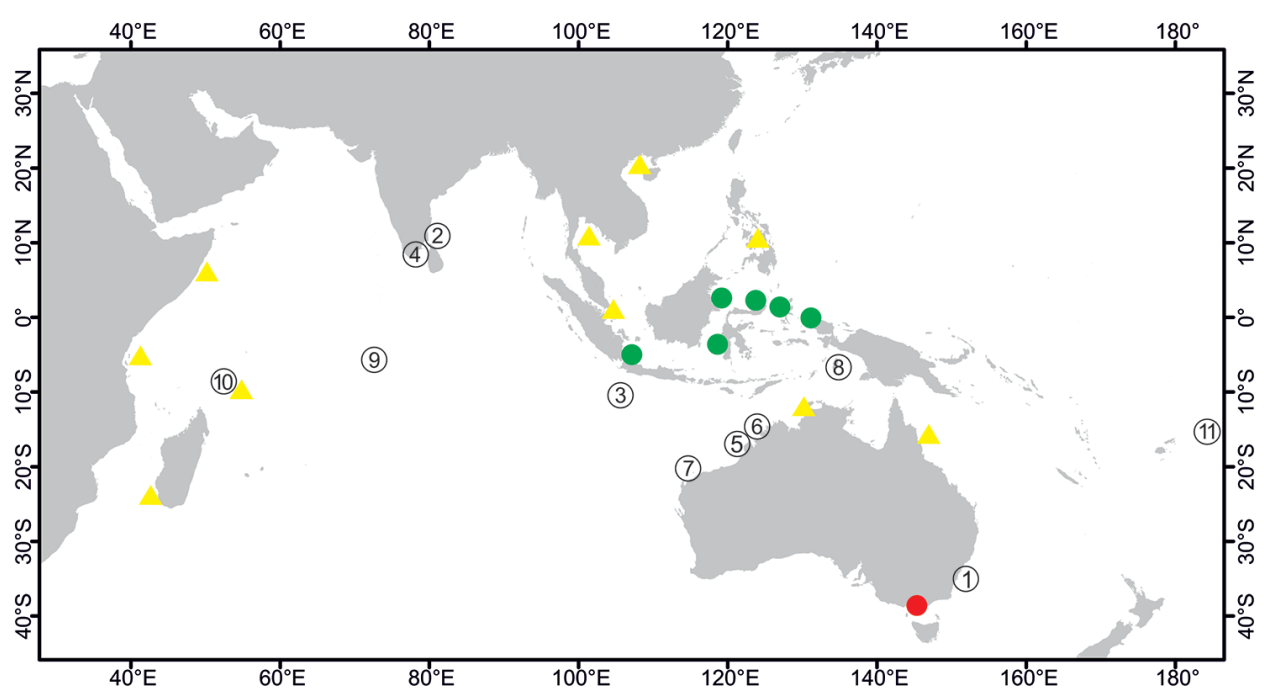

Figure 7. Distribution of Cinachyrella australiensis. Red dot: type locality, Tethya cranium var. australiensis Carter, 1886, Port Phillip Heads, Southeast Australia. Green dots: Indonesian localities where the species was collected recently. Yellow triangles: Non-Indonesian localities, Seychelles Islands, Southwest Madagascar, Zanzibar, Thailand, Singapore, Vietnam, Philippines, Northern Territory of Australia, and the Great Barrier Reef in Australia. Circled numbers: type localities of synonymized species I Spiretta raphidiophora Lendenfeld, 1888, Port Jackson, Sidney, Australia 2 Tetilla hirsuta Dendy, 1889, Gulf of Manaar, Sri Lanka 3 Tetilla lindgreni Lendenfeld, 1903, Christmas Island 4 Tetilla poculifera Dendy, 1905, Gulf of Manaar, Sri Lanka 5 Tethya hebes, 1907, at $19^{\circ}$ South on the NW coast of Australia 6 Cinachyra isis Lendenfeld, 1907, Mermaid Strait, NW Australia 7 Tetilla cinachyroides Hentschel, 1911, Barrow Island, NW Australia 8 Cinachyra nuda Hentschel, 1912, Aru Island, Indonesia 9 Cinachyra vaccinata Dendy, 1922, Diego Garcia, Chagos Islands 10 Cinachyra providentiae Dendy, 1922, Providence Island, Seychelles I I Cinachyrella anatriaenilla Fernandez, Kelly, Bell, 2017, American Samoa.

shed more light in this situation. It is quite possible that after a review of specimens from Southern Australia, it will be evident that the Indonesian specimens that we assign to $C$. australiensis should in fact be assigned to another species. In that case one of the junior synonyms should be used, e.g. C. raphidiophora or C. hirsuta.

Although our focus was on Indonesian species, it was unavoidable to attempt, for the first time after Burton's review (1934), check the status of his large list of junior synonyms, because some of them were described or later found in Indonesian localities. We gathered as many type specimens as possible, most of them repositories of the NHMUK (London) and NMNH (Washington DC). The main criteria we used to suggest a species as junior synonym of $C$. australiensis were the presence of acanthose microxea and that the mega- and micro-scleres have the same size range of the species. Therefore, here we include as junior synonyms the following species from Burton's list: Spiretta raphidiophora Lendenfeld, 1888; Tetilla hirsuta Dendy, 1889; Cinachyra isis Lenfenfeld, 1907; Tetilla cinachyroides Hentschel, 1911; Cinachyra nuda Hentschel, 1912; Cinachyra vaccinata Dendy, 1922; Cinachyra providentiae Dendy, 1922. They all fulfill the $C$. australiensis description. 


\section{Here we provide further remarks on the following species, in chronologic order:}

Tetilla lindgreni Lendenfeld, 1903 was described as a new species to separate it from T. ternatensis Kieschnick, 1896, as T. ternatensisis is a Paratetilla based on the presence of calthrop-like spicules. Lendenfeld noticed that both, Lindgren's (1898) and subsequently Kirkpatrick's (1900) material, lack such calthrop-like spicules, and instead, they have acanthose microxea similar to other Tetilla specimens described in his monograph (Lendenfeld 1903). From that material, we checked Kirkpatrick's specimens and suggest that $T$. lindgreni is a junior synonym of $C$. australiensis.

Tethya hebes Lendenfeld, 1907 has acanthose microxea and it has most of $C$. australiensis characters, yet it was excluded from Lendenfeld's Cinachyrinae-group (with porocalices) because he did not observe porocalices. The type specimens of $T$. hebes examined at the NHM (NHMUK 1908.9.24.66) are two small fragments, about 1.2 $\times 1 \mathrm{~cm}$, and it is not possible to observe neither discard the presence of porocalices. Apart from that, the general skeletal arrangement and spicule configuration suggest that $T$. hebes fulfil all other morphological characteristics of $C$. australiensis. Therefore, we suggest that $T$. hebes is a junior synonym of $C$. australiensis.

We exclude from $C$. australiensis some junior synonyms that are part of the schulzeigroup species proposed by Burton (1934). These species have smooth microxea and include Keller's (1891) species from the Red Sea, Cinachyra schulzei and Cinachyra trochiformis. The taxonomic case of $C$. schulzei becomes more complicated as Kieschnick $(1898,1900)$ described a new species named Tetilla schulzei from material collected in Amboine islands of Indonesia with porocalices and spicules diagnostic of Cinachyrella, including microxea. However, Kieschnick did not mention any observation whether or not the microxea of T. schulzei have acanthose surface. The set of characters of Cinachyra schulzei Keller, 1891 and Tetilla schulzei Kieschnick, 1898 correspond to Cinachyrella. However, we consider that both species should be treated as homonyms because they were described under two different genera, from different and distant localities and we were not able to find their type material to verify if they could be synonymized. Other species within the schulzei-group are Cinachyra mertoni Hentschel, 1912 from Kei island in Indonesia; Tetilla poculifera Dendy, 1905 from Sri Lanka; and Chrotella ibis Row, 1911 from the Red Sea. Special attention and a further revision is proposed for the schulzei-group of species, as we did not observe any specimen of the genus Cinachyrella with smooth microxea within the Indonesian material examined in this study. It is important to mention that thin smooth microxea were observed in both Paratetilla species, P. bacca and P. arcifera, but they also have calthrops as a diagnostic character of the genus.

We also exclude from $C$. australiensis two of the junior synonyms still present in the WPD (van Soest et al. 2018). First, Tethya armata Baer, 1906, because it is clear from the description that this species has a proteinous cortex reinforced by microxeas, resembling other Craniella species. Second, we exclude the junior synonym Cinachyra malaccensis Sollas, 1902, as the description does not mention the presence of microxea, therefore we suggest to synonymise it with $C$. porosa. 

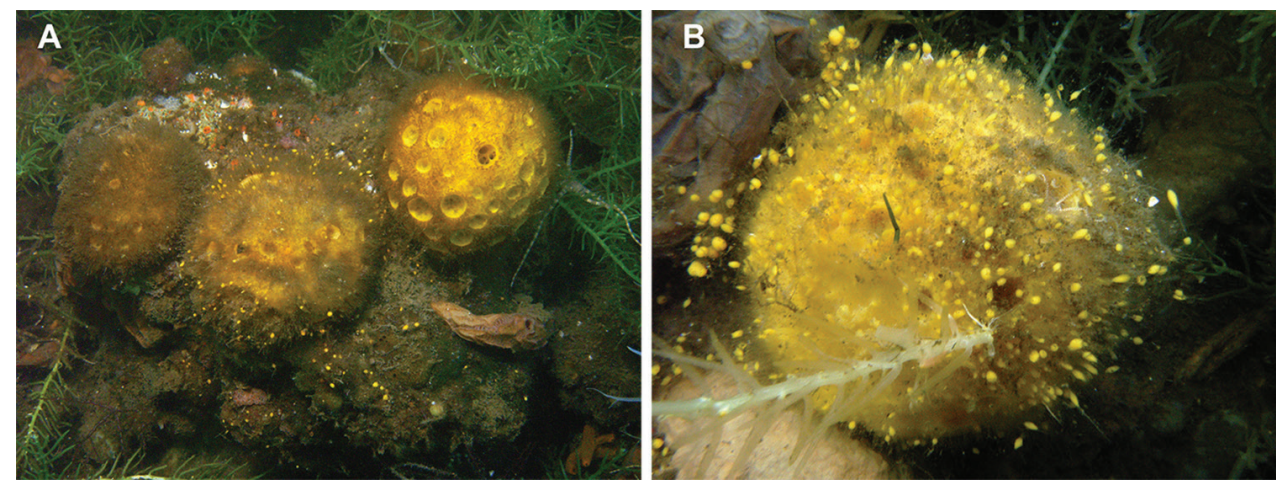

Figure 8. Budding and sediment capture of Cinachyrella species A Three individuals of C. porosa in Haji Buang lake, East Kalimantan, Indonesia, showing distribution of buds beyond the individuals and sediment capture B Close up of $C$. porosa with detail of buds. Each individual is approximately $4 \mathrm{~cm}$ in diameter.

In our view, the recently erected species of Cinachyrella anatriaenilla is junior synonym of $C$. australiensis, because the oxea and the microscleres fall within the size range of the type species of $C$. australiensis as well as the specimens we have included in this review. The authors distinguish their species from $C$. australiensis on the basis of having only one category of oxeas versus two categories in $C$. anatriaenilla. However, we do not recognize size classes in oxea in any of the Cinachyrella specimens and types, but rather a continuos range in size (1000-5500 $\mu \mathrm{m}$ for $C$. australiensis). The oxea of $C$. anatriaenilla fall within the size range of the type specimen of $C$. australiensis as well as the other reviewed material of $C$. australiensis. In addition, the authors based their statements on the revision of the type specimen of $C$. kuekenthali, which is from the west Atlantic, but they did not review the type specimen of $C$. australiensis nor any of the other species with acanthose microxea from the Indo-Pacific.

Recent molecular studies (Szitenberg et al. 2013, Schuster et al. 2017) show that Cinachyrella is a polyphyletic genus. It is beyond the scope of the current study to review the taxonomic status of the genus Cinachyrella. Within C. australiensis there are different genotypes (Schuster et al. 2017) that possibly represent morphologically cryptic species. Among the high morphological variation observed within our Indonesian specimens, some trends could be highlighted among the different populations. For instance, specimens from reefs of Berau were generally larger (up to $8 \mathrm{~cm}$ in diameter) and their porocalices had a bottle-shape with a small aperture (1 to $4 \mathrm{~mm}$ ) and the cavity was often occupied by a shrimp. Although these characteristics resemble $C$. providentiae, the latter is one of the junior synonyms that we propose for $C$. australiensis based on spicule dimensions and forms. Specimens from Raja Ampat generally had smaller acanthose microxeas (Table 6), while in some specimens collected in marine lakes few abnormal spicules were observed. Yet, in all cases we could not detect consistent, quantifiable morphological differences. 


\section{Cinachyrella porosa (Lendenfeld, 1888)}

Figs 9, 10

Spiretta porosa Lendenfeld, 1888: 43 (type seen).

Cinachyra malaccensis Sollas, 1902: 219, pl. XIV, fig. 2; pl. XV, fig. 5. Malacca Strait. Tetilla porosa; Lendenfeld, 1903: 22.

Tetilla anomala Dendy, 1905: 91, pl. III, fig.5 (type seen).

Cinachyra albatridens Lendenfeld, 1907: 149, pl. XV, figs 7-9 (type seen).

Cinachyra albaobtusa Lendenfeld, 1907: 154, pl. XVI, figs 45-52 (type seen).

Cinachyra albabidens Lendenfeld, 1907: 151, pl. XVI, figs 39-44 (type seen).

Tethya clavigera Hentschel, 1912: 327, pl. XVI, fig.1, pl. XVIII, fig. 10 In Aru Island,

Beach Ngaiboor Trangan.

Cinachyra anomala; Dendy, 1922: 20, pl. 1, fig. 3 (material seen).

Cinachyra porosa; de Laubenfels, 1954: 240, pl. XI, fig. b (material seen).

Material examined. Holotype NHMUK 1886.8.29.632-633, Port Denison, Australia (as Spiretta porosa). NHMUK 1907.2.1.12, Chilaw, Sri Lanka (as Tetilla anomala). NHMUK 1908.2.9.40-42, Diego Garcia, Chagos Archipelago (as Cinachyra albatridens). NHMUK 1908.9.24.72, Anachoreten (=Keniet) Islands, Papua New Guinea (as Cinachyra albaobtusa). NHMUK 1908.9.24.71, Tonga Islands (as Cinachyra albabidens). INDONESIA, East Kalimantan, Berau reef, RMNH. POR.11228 [LT628324]; Pea Bay, RMNH.POR.11242, RMNH.POR.11243, RMNH.POR.11244 [JX177888]; Bamban Lake, RMNH.POR.11222, RMNH. POR.11223, RMNH.POR.11224, RMNH.POR.11225 [LT628327], RMNH. POR.11226; RMNH.POR.11226; Bandong Lake, RMNH.POR.11227; Haji Buang Lake, RMNH.POR.11236, RMNH.POR.11237, RMNH.POR.11238, RMNH. POR.11239, RMNH.POR.11240 [LT628325], RMNH.POR.11230, RMNH. POR.11231, RMNH.POR.11232 [LT628326], RMNH.POR.11233, RMNH. POR.11234, RMNH.POR.11235, RMNH.POR. 3514; Kakaban Lake, RMNH. POR.11241. Java, Thousand Islands, RMNH.POR.1998, RMNH.POR.2108. Sulawesi, Bunaken, RMNH.POR.3105. Ternate, Ternate reef, RMNH.POR.11309. West Papua, Sawaundarek Lake, RMNH.POR.11245 [JX177884], RMNH. POR.11246 [LT628323], RMNH.POR.11247, RMNH.POR.11248; Ctenophore Lake, RMNH.POR.11249, RMNH.POR.11250, RMNH.POR.11251, RMNH. POR.11251， RMNH.POR.11252， RMNH.POR.11253， RMNH.POR.11254, RMNH.POR.11255, RMNH.POR.11256, RMNH.POR.11257, RMNH. POR.11258, RMNH.POR.11259; Outside Ctenophore Lake, RMNH.POR.11260, RMNH.POR.11261, RMNH.POR.11262; Gam Island, Reef flat, RMNH. POR.11263; Gam Island, Mangrove, RMNH.POR.11264.

Description. External morphology. Globular sponges, size from 3 to $5 \mathrm{~cm}$ in diameter (Figs 9A, 10A, B). Surface highly hispid due to the projecting spicules, covered by numerous porocalices. Porocalices are bowl-shape, with rounded apertures, up to $4 \times 5 \mathrm{~mm}$ and $5 \mathrm{~mm}$ deep, abundant; no cloaca; in preserved material some porocalices are closed. 


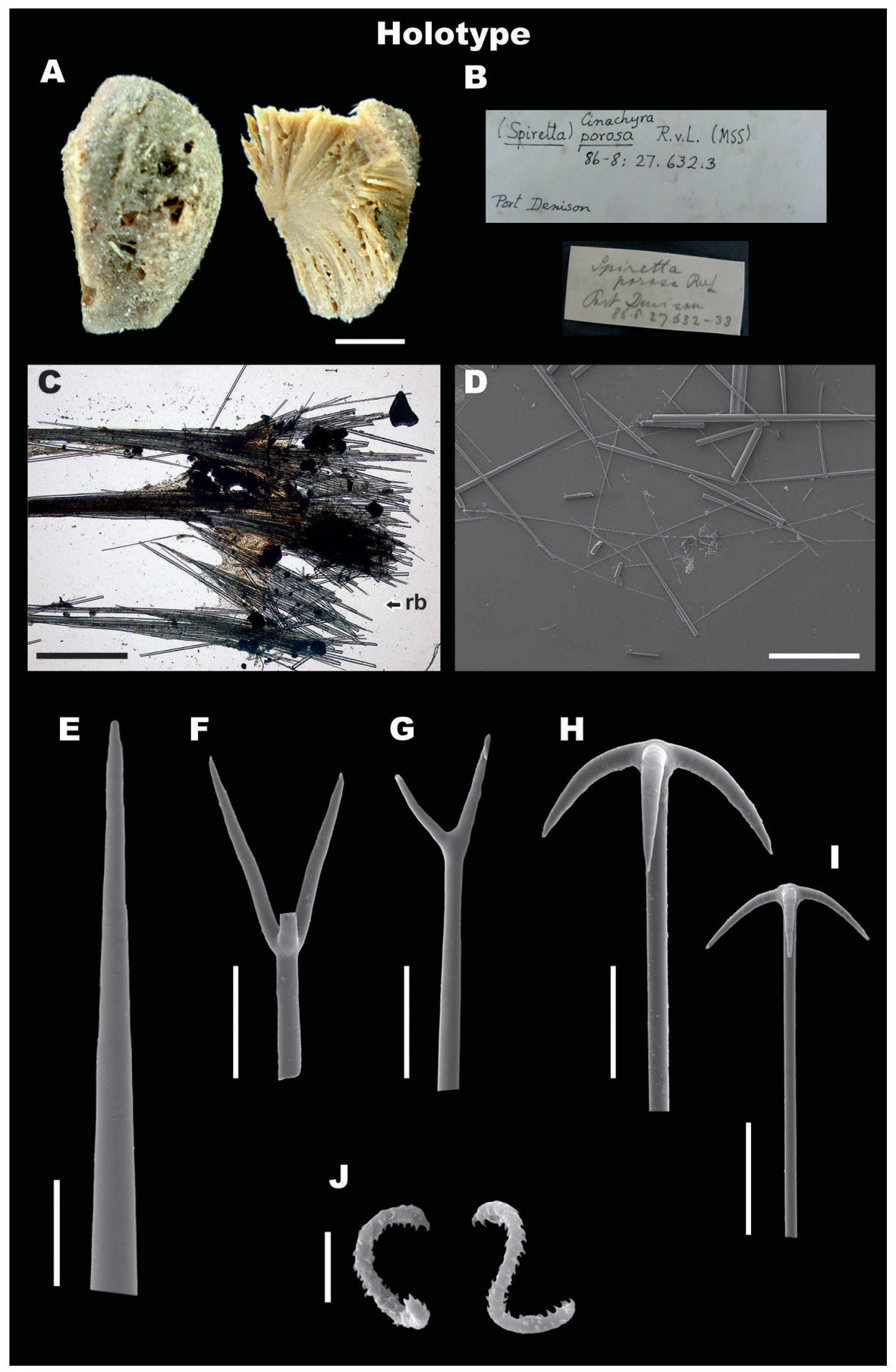

Figure 9. Cinachyrella porosa. Holotype NHMUK1886.8.29.632-633, Port Denison, Australia. A preserved material showing porocalices and internal structure B Labels of the type specimen $\mathbf{C}$ skeleton $\mathbf{D}$ electron micrograph showing oxea fragments and triaenes rhabds $\mathbf{E}$ oxea, end detail $\mathbf{F}$ protriaene $\mathbf{G}$ prodiaene $\mathbf{H}, \mathbf{I}$ anatriaenes $\mathbf{J}$ sigmaspires. Scale bars: $1 \mathrm{~cm}(\mathbf{A}, \mathbf{C}) ; 500 \mu \mathrm{m}(\mathbf{D}) ; 50 \mu \mathrm{m}(\mathbf{E}) ; 40 \mu \mathrm{m}(\mathbf{F}-\mathbf{I}) ; 5 \mu \mathrm{m}(\mathbf{J})$. 


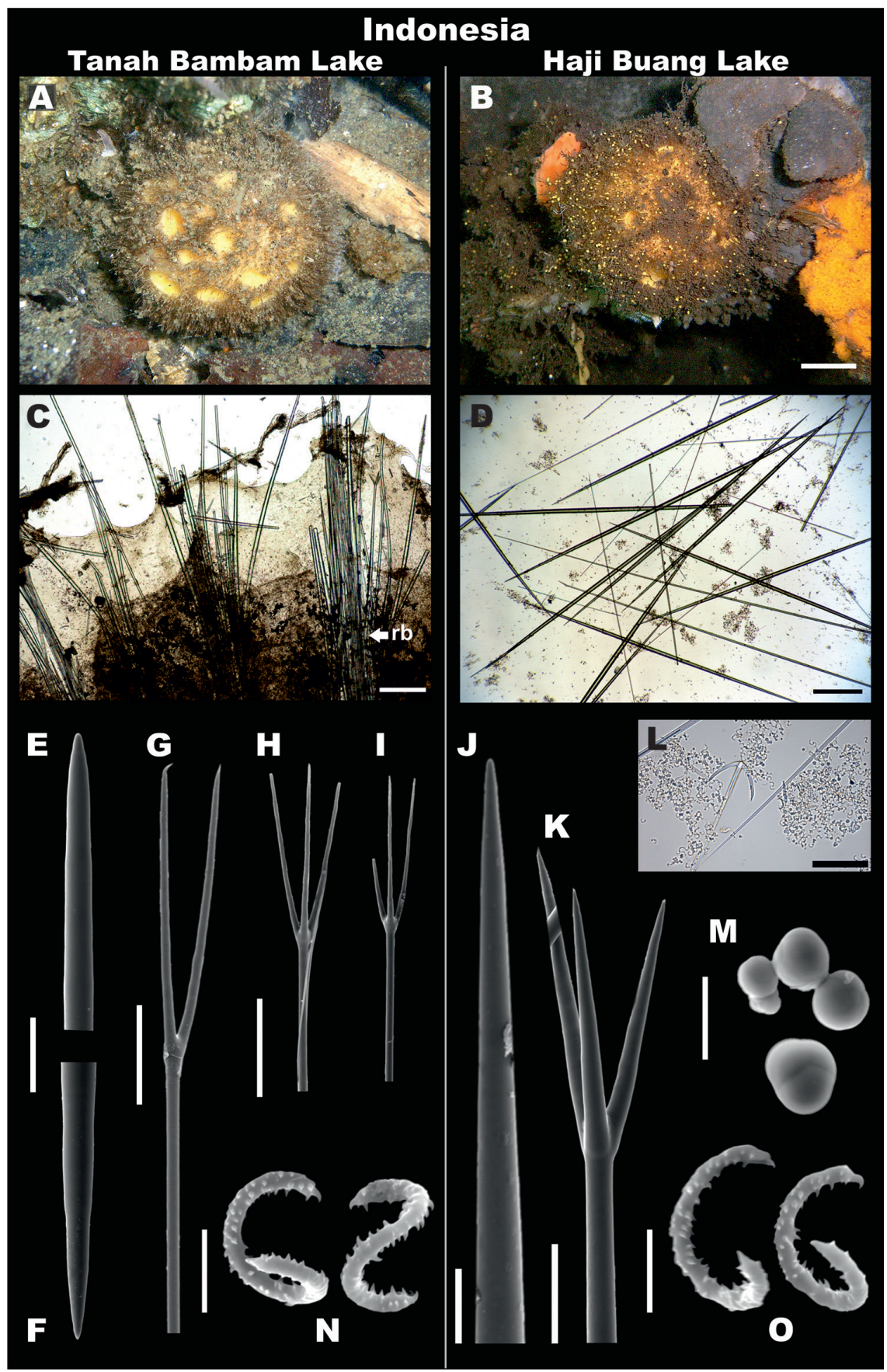

Figure 10. Cinachyrella porosa from Indonesia. A, C, E-I, N, RMNH.POR.11223, Tanah Bambam Lake. B,D, J-M, O RMNH.POR.11235, Haji Buang Lake A-B In situ photographs; C skeleton, showing radial bundles and triaenes $\mathbf{D}$ spicules in light microscope showing oxeas and triaenes rhabds $\mathbf{E}, \mathbf{F}$ oxea, end details $\mathbf{G}$ prodiaene $\mathbf{H}, \mathbf{I}$ protriaene $\mathbf{J}$ oxea, end detail $\mathbf{K}$ protriaene $\mathbf{L}$ anatriaene in light microscopy $\mathbf{M}$ spheres $\mathbf{N}, \mathbf{O}$ sigmaspires. Scale bars: $500 \mu \mathrm{m}(\mathbf{C , D}) ; 20 \mu \mathrm{m}$ (E,F,J); $40 \mu \mathrm{m}$ (G-I, K); $100 \mu \mathrm{m}$ (L); $5 \mu \mathrm{m}$ (M-O). 
Color generally yellow when alive (Figure 10A, B), which turns paler or even white-grey after preservation in ethanol (Figure 9A).

Skeleton. No cortex. Skeleton composed by bundles of oxeas and triaenes radiating from a central core (Figs 9C, 10C).

Megascleres. Measurements are shown in Table 6 for the holotype and Indonesian specimens. Holotype, oxeas 820-2553.2-3750 $\mu \mathrm{m} \times 7.5-29.4-47.5 \mu \mathrm{m}$ (Figure 9C-E); few anatriaenes (Figure 9H, I), with rhabd always broken 2.5-7.3-15 $\mu \mathrm{m}$, cladi thin, with obtuse angles 50-67.6-100 $\mu \mathrm{m} \times 30-42-60 \mu \mathrm{m} \times 2.5-5.6-7.5 \mu \mathrm{m}$; protriaenes less abundant (Figure 9F), with rhabd always broken up to $5800 \mu \mathrm{m} \times$ 5-7.3-12.5, probably tapering to dimensions $<1 \mu \mathrm{m}$, with thin and long cladi (25$44.4-65 \mu \mathrm{m} \times 35-73-110 \mu \mathrm{m} \times 5-5.1-7.5 \mu \mathrm{m})$; abundant prodiaenes with similar dimensions as protriaenes (Figure 9G).

Microscleres. No microxeas. Sigmaspires 5-8.6-12.5 $\mu \mathrm{m}$ in the holotype (Figure 9J) and 5-8.4-12.5 in the Indonesian specimens (Figure 10N, O), C-S shape; in some Indonesian specimens, silica spheres ranging from 3-7 $\mu \mathrm{m}$ in diameter can be present (Figure 10M).

Ecology. Occurs in reefs, mangroves, and marine lakes. Predominantly in shallow areas. Notably, a large population inhabit the marine lake of Tanah Bambam, where $C$. porosa was the dominant representative of moon sponges. This species produces 1-2 mm sized buds (Figure 8) and buds extensively in marine lakes habitats.

Distribution. According to the material examined in this revision, we observed that this species is widely distributed in the Indo-Pacific, from the Chagos archipelago, Sri Lanka, Australia, and Tonga Islands. In Indonesia, C. porosa has been collected in East Kalimantan, Java, Ternate, and West Papua.

Remarks. Cinachyrella porosa is distinguished from $C$. australiensis by the absence of acanthose microxea and smaller size of sigmaspires. The first species described with these two diagnostic characteristics was Spiretta porosa Lendenfeld, 1888, subsequently transferred to the genus Tetilla (Lendenfeld 1903) and included as a junior synonym of $C$. australiensis in both, Burton (1934) and WPD (2018). The detailed examination of the holotype of $C$. porosa suggests that this species should therefore be resurrected. Based on the careful examination of the holotypes of C. albabidens (Lendenfeld, 1907) and C. albaobtusa (Lendenfeld, 1907), and the descriptions and plates of C. malaccensis (Sollas, 1902) and C. clavigera (Hentschel, 1912), we coincide with the porosagroup recognized by Burton (1934). However, we disagree with the statement that intermediate forms can be found within the wide range of variation of $C$. australiensis, and therefore we consider $C$. porosa as a valid species clearly differentiated from $C$. australiensis. Lendenfeld (1907) recognized the difficulties to separate the three species of the alba-group, and his decision to discriminate them as different species was based on distant localities and slight differences on the abundance of triaenes. After the morphological analysis of the $C$. albatridens holotype, we consider that this species could also be a junior synonym of $C$. porosa because neither microxea nor other characters to separate this species were found. Although Burton (1934) did not consider $C$. anomala (Dendy, 1905) within the porosa-group, we suggest that a similar decision could be 


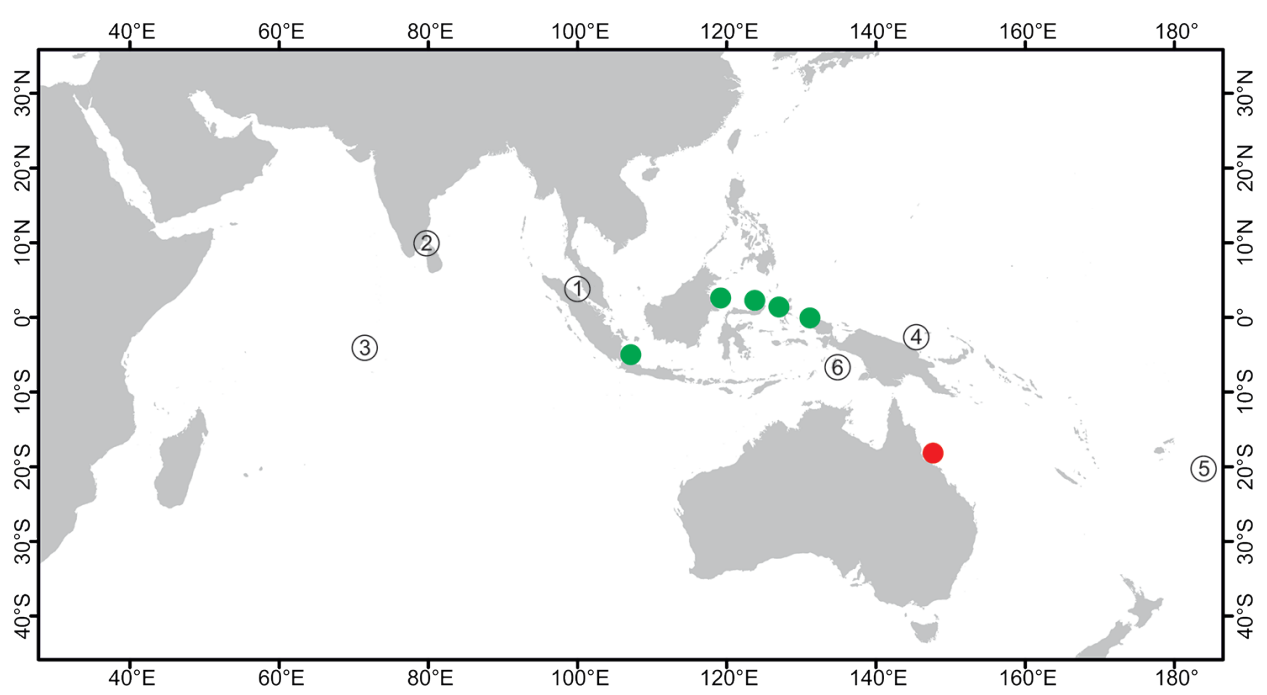

Figure I I. Distribution of Cinachyrella porosa. Red dot: type locality, Spiretta porosa Lendenfeld, 1888, Port Denison, Queensland, Australia. Green dots: Indonesian localities where the species was collected recently. Circled numbers: type localities of synonymized species I Cinachyra malaccensis Sollas, 1902, Malacca Strait, Malaysia 2 Tetilla anomala Dendy, 1905, Chilaw, Sri Lanka 3 Cinachyra albatridens Lendenfeld, 1907, Diego Garcia, Chagos Archipelago 4 Cinachyra albaobtusa Lendenfeld, 1907, Anachoreten (=Keniet) Islands, Papua New Guinea 5 Cinachyra albabidens Lendenfeld, 1907, Tonga Islands 6 Tethya clavigera Hentschel, 1912, Aru Island, Indonesia.

made based on our observations of the type specimen. Some of the Indonesian specimens have silica micro-spherules. Similar spherules have been described for species C. anomala and C. hirsuta (Dendy, 1905), as well as Tetilla cinachyroides (Hentschel 1911). Because C. hirsuta and T. cinachyroides contain acanthose microxea, they are synonimized with $C$. australiensis. The nature of these spherules has been discussed by Dendy (1905) and Lendenfeld (1907). Dendy (1905) suggests that the spherules are associated with mother cells, which probably would give origin to sigmaspires, or they can be considered as anomalous or incidental spicules. On the other hand, Lendenfeld (1907) estimated that spherules are the earlier stages of oxeas as described for Tethya cranium (see Lendenfeld 1907, plate 14 figs 11-15). Silica spherules are very variable within populations of the same species and among different genera in Tetillidae, suggesting that this character has no taxonomic value.

\section{Cinachyrella paterifera (Wilson, 1925)}

Figs 12, 13

Tetilla (Cinachyrella) paterifera Wilson, 1925: 375; plate 39, figs 6, 8; plate 48, fig. 4 (type seen). 
Material examined. Holotype USNM21314, South of Tumindao Reef, Tibutu Island, Sibutu Group, Sulu Archipelago, Philippines, 18 m, 27 Feb 1908. INDONESIA. East Kalimantan, Berau reef, RMNH.POR.11207; RMNH.POR.11208; RMNH.POR.11209; RMNH.POR.11211. West Papua, Wallace Lake, RMNH. POR.11212, RMNH.POR.11213, RMNH.POR.11214; Outside Wallace Lake, RMNH.POR.11215; Gam Island, RMNH.POR.11216, RMNH.POR.11217, RMNH.POR.11218, RMNH.POR.11219, RMNH.POR.11220; Ctenophore Lake, RMNH.POR.11221.

Description. External morphology. Globular sponges, size from 5 to $7 \mathrm{~cm}$ in diameter attached to the substrate by a large peduncle/shaft $3 \times 2.5 \mathrm{~cm}$ (Figure $12 \mathrm{~A}$, B). Surface smooth to hispid due to the projecting spicules, covered by porocalices. Porocalices are bowl or pocket-shape, with rounded apertures, up to $5 \times 7 \mathrm{~mm}$ and 2-4 mm deep; a central cloaca is located on the top, $15 \times 12 \mathrm{~mm}$ in diameter and 10 $\mathrm{mm}$ deep. Color bright pink when alive, which turns slightly paler in ethanol. Skeleton composed by bundles of oxeas and triaenes radiating from a central core. No cortex.

Megascleres. The holotype and Indonesian measurements are shown in Table 6. Holotype, oxeas 1400-3011.5-4750 $\mu \mathrm{m} \times 10-34.5-62.5 \mu \mathrm{m}$ (Figure 12D, I); few anatriaenes (Figure 12L), with a thick, small, poorly developed cladi, 17.5-24.2-30 $\mu \mathrm{m} \times$ 2-6.5-10 $\mu \mathrm{m} \times 5-5.8-7.5 \mu \mathrm{m}$, rhabd slightly thicker in the middle $15-25 \mu \mathrm{m}$, and tapering to dimensions of $<1 \mu \mathrm{m}$.; two different types of protriaenes, first one rare, with thick and small cladi (Figure 12K), 30-32.5-35 $\mu \mathrm{m} \times 22.5-31.3-40 \mu \mathrm{m} \times 7.5-7.5-7.5$ $\mu \mathrm{m}$, rhabd usually broken, up to $5000 \times 10 \mu \mathrm{m}$, thicker in the middle $40 \mu \mathrm{m}$, and tapering to dimensions of $<1 \mu \mathrm{m}$, the second type smaller, very abundant around porocalices, with small cladi in acute angle (fork-shape), 7.5-12.5-17.5 $\mu \mathrm{m} \times 12-15.5-20$ $\mu \mathrm{m} \times 2.5-2.5-2.5 \mu \mathrm{m}$, rhabd up to $820 \times 2.5 \mu \mathrm{m}$; strongyles are common, although only broken spicules observed in the holotype (Figure 12J), Indonesian specimens are 1800-2545.8-3700 $\mu \mathrm{m} \times 35-42.7-62.5 \mu \mathrm{m}$ (Figure 12F); no calthrop-like triaenes.

Microscleres. No microxeas; sigmaspires 10-13.2-17.5 $\mu \mathrm{m}$ in the holotype (Figure $12 \mathrm{~N}$ ) and 10-14.8-20 $\mu \mathrm{m}$ in Indonesian material (Figure 12M); C-S shape.

Ecology. The species occurs mainly in reefs, and it is rare in marine lakes and mangroves. It usually inhabits sand bottoms, in which the penduncle serves as a support structure.

Distribution. Indonesia, including East Kalimantan and West Papua. It is also known from Sibutu Island in Philippines (Wilson 1925). Although it is found in a variety of habitats, C. paterifera is the least common species of Cinachyrella from Indonesia.

Remarks. Cinachyrella paterifera has a characteristic elongated peduncle, it is pink to violet colored, and it contains abnormal anatriaenes. Interestingly, Wilson (1925) described rare microxeas $(250 \times 2 \mu \mathrm{m})$ in one specimen of the type series, whilst they were very abundant in the other two types. After a detailed examination of the type specimen USNM 21314 and preparations from different parts of the individual sponge, no microxeas were observed, suggesting that this character is not diagnostic of the species. Although C. tenuiviolacea (Pulitzer-Finali 1982) from the Great Barrier Reef resembles $C$. paterifera in the distinctive pink to violet color and presence 

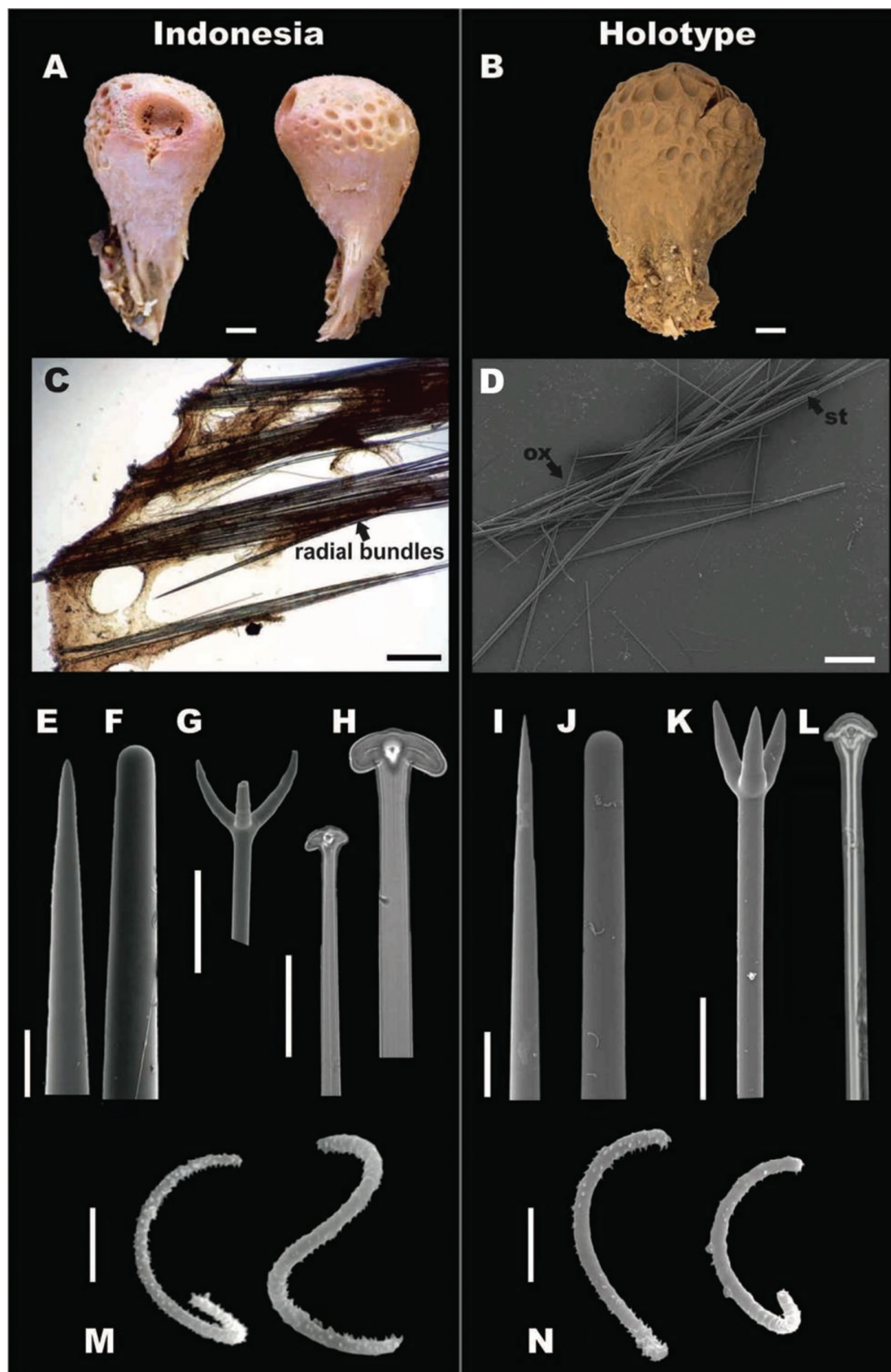

Figure I 2. Cinachyrella paterifera. A, C, E-H, M RMNH.POR.11207, Berau Reef, Indonesia (left side). B, D, I-L, N holotype USNM 21314, Timundao Reef, Sulu Archipelago, Philippines (right side) A specimen recently collected showing typical pink color, porocalices and stalk B Holotype, showing porocalices and stalk $\mathbf{C}$ skeleton showing radial bundles $\mathbf{D}$ spicules showing oxeas (ox) and strongyle (st), (scale bar $500 \mu \mathrm{m}$ ); $\mathbf{E}$ oxea, end detail $\mathbf{F}$ strongyle, end detail $\mathbf{G}$ protriaene $\mathbf{H}$ anatriaenes with short or abnormal cladus $\mathbf{I}$ oxea, end detail $\mathbf{J}$ strongyle, end detail $\mathbf{K}$ protriaenes $\mathbf{L}$ anatriaene with short or abnormal cladus $\mathbf{M}, \mathbf{N}$ sigmaspires. Scale bars: $1 \mathrm{~cm}(\mathbf{A}, \mathbf{B}) ; 500 \mu \mathrm{m}(\mathbf{C}, \mathbf{D}) ; 40 \mu \mathrm{m}(\mathbf{E}-\mathbf{L}) ; 5 \mu \mathrm{m}(\mathbf{M}, \mathbf{N})$ 


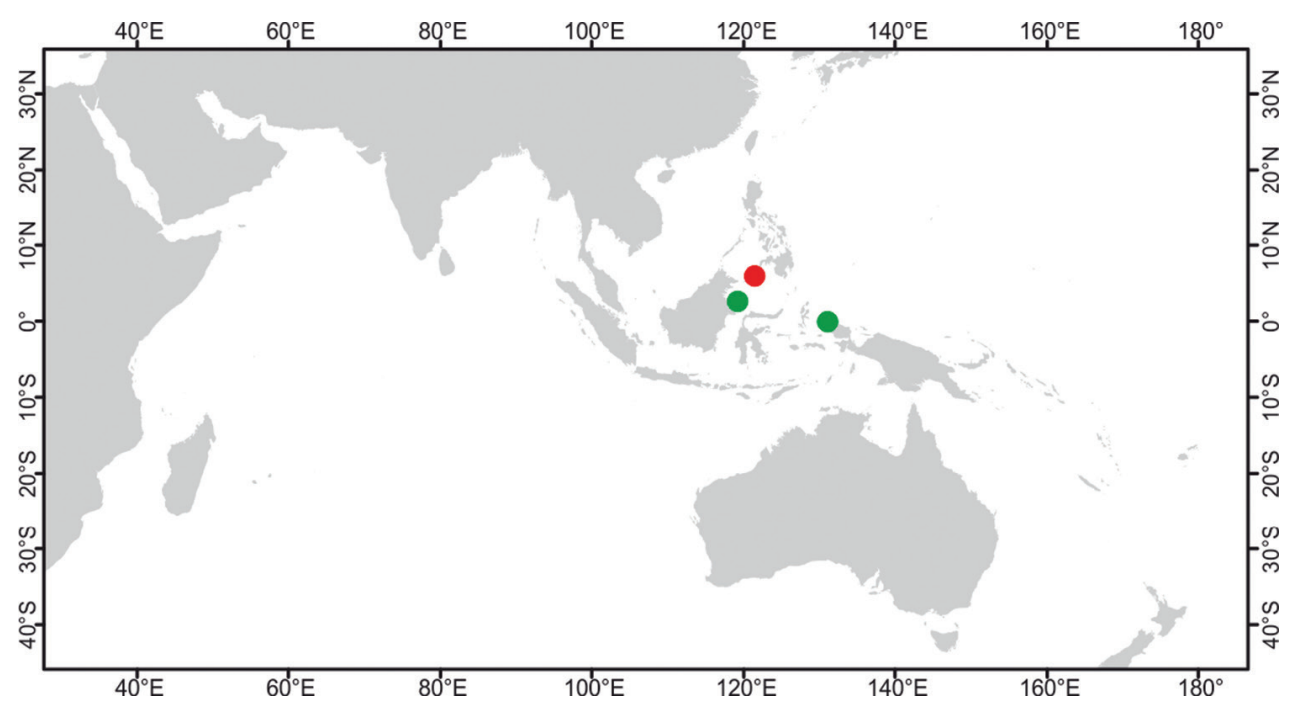

Figure 13. Distribution of Cinachyrella paterifera. Red dot: type locality, Tetilla (Cinachyrella) paterifera Wilson, 1925, Sibutu Island, Philippines. Green dots: Indonesian localities where the species was collected recently.

of abnormal anatriaenes, it remains to be investigated if these two species could be synonymized. We could not access type material from $C$. tenuiviolacea, and from the bad conditions of preservation noted by Pulitzer-Finali (1982) in his type specimen, it is not possible to determine whether the specimen has or does not have the peduncle characteristic of $C$. paterifera. The large numbers of hair-like protri- and prodiaenes around the porocalices of $C$. paterifera, resemble those described for C. vaccinata (Dendy, 1905), yet the C. vaccinata type contains acanthose microxea characteristic of C. australiensis. Cinachyrella paterifera share with C. porosa the absence of microxea, but they differ by the larger sigmaspires and abnormal protriaenes of $C$. paterifera. Indonesian specimens vary within the morphological range of the species. Specimens of this species belong to the same phylogenetic clade supporting its monophyly (Szitenberg et al. 2013; Schuster et al. 2017).

\section{Identification key for Indonesian Paratetilla and Cinachyrella species}

1 Porocalices present; calthrops

- $\quad$ Porocalices present; no calthrops, all triaenes -if present- are long-shafted....

2 Trichodragmata present 
Microxea present.

Acanthose microxea present $(115-270 \mu \mathrm{m})$; sigmaspires 10-20 $\mu \mathrm{m}$

Cinachyrella australiensis

6 Small sigmaspires (5-10, few up to $12.5 \mu \mathrm{m}$ ), generally yellow color and ballshape

- $\quad$ Large sigmaspires (10-20 $\mu \mathrm{m})$, generally pink color, sometimes with peduncle to attach it to the substrate, pear-shape; protriaenes in two different classes; few anatriaenes with reduced and deformed cladi

Cinachyrella paterifera

\section{Final remarks}

Our results contribute to the understanding of the taxonomy and systematics of the Indo-Pacific tetillids. A review of the taxonomic history of the genus Paratetilla and the species Cinachyrella australiensis, showed some cases of misinterpreted synonyms, misidentifications and lack of detailed descriptions for some species. The concept of a single widespread species is refuted for Paratetilla bacca (Dendy 1922, Burton 1959) as well as for Cinachyrella australiensis (Burton 1934). A wide morphological variation within moon sponges was observed for specimens collected in Indonesia. Among our material, we recognize three Paratetilla and four Cinachyrella species occurring in Indonesia, inhabiting a variety of habitats such as marine lakes, coral reefs, and mangroves. We are resurrecting $P$. arcifera Wilson 1925 and C. porosa (Lendenfeld, 1888) as valid species. The majority of the holotypes were studied for the current study; the ones we did not review were either unavailable or the description of the text was clear and comprehensive.

The species of Paratetilla and Cinachyrella are clearly highly adaptable and widely distributed sponges. All species in the current study are distributed across Indonesia. It is remarkable that they are all sympatric, some species occuring together in the same marine lake. We have reviewed specimens from East Kalimantan, North Sulawesi, and West Papua. It is highly likely that there are more species in Indonesia in regions that have not been sampled as extensively. Further investigations into Paratetilla and Cinachyrella from the Molluccas, Nusa Tenggara, South Kalimantan, Eastern Papua, and also the virtually unexplored deep sea of Indonesia, will likely lead to the discovery of more species within these genera. Most species occur in all studied habitats (marine lakes, mangroves, and reefs) with a high degree of tolerance for high temperature and sedimentation, as has been observed in other families of sponges (Schönberg 2015). The exceptions to this high tolerance were $P$. arcifera and $C$. paterifera, which were only seen in reefs with little sedimentation or sediment resuspension. High budding was observed in specimens of Cinachyrella australiensis and C. porosa residing in marine lakes, while no budding was observed in the same species in the reefs. Singh and Thakur 
(2015) revealed temperature as the most prominent factor regulating the intensity of budding in Cinachyrella cf. cavernosa.

Previous molecular phylogenetic studies indicate that P. bacca, P. arcifera, C. porosa, and $C$. paterifera are distinct monophyletic species, while Cinachyrella australiensis may consist of a species complex with morphologically cryptic species (Schuster et al. 2017). In the specimens that we identify as $C$. australiensis we do not find any consistent differences in spiculation to validate distinct species, in spite of the different haplotypes that are found within our specimens. Carella et al. (2016) also found that several well-supported subgroups within the Cinachyrella clade might correspond to subgenera. We were not able to distinguish multiple species with our set of $C$. australiensis specimens using standard morphological characters. Among the reviewed literature, we also observed that there is a tendency among people making inventories of reef species to name any yellow or yellow-orange tetillid ball $C$. australiensis. It is clear that the genus Cinachyrella and in particular the species $C$. australiensis require further analysis using either other molecular markers or morphological characters that go beyond the aims of the current study. We hope that our detailed study, images, and key will ensure that species from Paratetilla and Cinachyrella will be identified correctly based on morphological characters. It is important to understand the distinction between species, as there is a growing interest in natural products and other biobased studies from tetillids (e.g. Cleary et al. 2013, Mokhlesi et al. 2017, Zhang et al. 2017). We expect that the current study can provide a solid basis for subsequent species descriptions of Indo-Pacific species of the genera Cinachyrella and Paratetilla.

\section{Acknowledgements}

We greatly appreciate the valuable help and discussions with Dr. NJ de Voogd and Dr. RWM van Soest. We credit Dr. RWM van Soest for thinking of the common name 'Moon sponges'. Ms. Estradivari and Mr. Bahruddin were indispensable in our quest for Cinderellas. We would like to thank the following people for their help in field logistics and/or lab assistence: Dr. B Hoeksema, Dr. Suharsono, Dr. Y Tuti, Dr. Abdunnur, Mr. M Ammer, Dr. M Erdmann, Ms. E Dondorp, Dr. W Renema, Ms. E Oberhauser, Dr. E Gittenberger, Mr. J van Oyen, Mr. E van Egmond, Mr. R Suhr, Dr. $\mathrm{H}$ Breeuwer, and the staff of Papua Diving, TNC/WWF Berau Office, Nabucco Island Dive Resort, Derawan Dive Resort, and at the molecular labs of IBED UvA and Leiden University. Mrs. C Valentine, Mr. A Cabrinovic, Ms. E Sherlock and Dr. T White are acknowledged for making available type specimens at the NHM London, and Dr. K Rützler at the NMNH in Washington DC. NS was funded by the Alßan Programme (code E07M402757CO) and LEB funded by NWO, division Earth and Life Sciences (\# 817.01.008, \#825.12.007, and \#863.14.020). Fieldwork in Indonesia was made possible through additional financial support of World Wildlife Foundation Netherlands-INNO Fund, the Schure-Beijerinck-Popping Fund of the Royal Dutch Academy of Science (KNAW), National Geographic Waitt Grant, the Treub-Maatschappij 
Fund, the Leiden University Fund (LUF)/Slingelands, Singapore Airlines, the AM Buitendijk Fund and the JJ ter Pelkwijk Fund. Examination of type specimens was possible thanks to EDIT Fellowships for Women Scientists to NS at the NHM and to LB at the NMNH. We are grateful to the Indonesian Institute of Sciences (LIPI) and the Indonesian State Ministry of Research and Technology (RISTEK) for providing research permits in Indonesia.

\section{References}

Alvarez B, Crisp MD, Driver F, Hooper JNA, van Soest RWM (2000) Phylogenetic relationships of the family Axinellidae (Porifera: Demospongiae) using morphological and molecular data. Zoologica Scripta 29: 169-198. https://doi.org/10.1046/j.1463-6409.2000.00029.x

Alvarez B, Krishnan M, Gibb K (2007) Analysis of intragenomic variation of the rDNA internal transcribed spacers (ITS) in Halichondrida (Porifera: Demospongiae). Journal of the Marine Biological Association of the United Kingdom 87: 1599-1605. https://doi. org/10.1017/S0025315407058407

Avise JC (2000) Phylogeography: The history and formation of species. Harvard University Press, $441 \mathrm{pp}$.

Azzini F, Calcinai B, Cerrano C, Bavestrello G, Panzini M (2007) Sponges of the marine karst lakes and of the coast of the islands of Ha Long Bay (North Vietnam). In: Custodio MR, et al. (Eds) Porifera research: Biodiversity, Innovation and Sustainability. Museo Nacional, Rio de Janeiro, 157-164.

Baer L (1906) Silicispongien von Sansibar, Kapstadt and Papeete. (Inaugural Dissertation: Berlin). Archiv für Naturgeschichte 72(1,1): 1-32.

Becking LE, Cleary DF, de Voogd NJ, Renema W, de Beer M, van Soest RWM, Hoeksema BW (2006) Beta-diversity of tropical marine assemblages in the Spermonde Archipelago, Indonesia. Marine Ecology 27: 76-88. https://doi.org/10.1111/j.1439-0485.2005.00051.x

Becking LE (2008) Marine lakes sponge fauna. In: Hoeksema BW, SET van der Meij (Eds) Cryptic Marine Biota of the Raja Ampat Island Group - Progress report. LIPI-Naturalis.

Becking LE, Renema W, Santodomingo NK, Hoeksema BW, Tuti Y, de Voogd NJ (2011) Recently discovered landlocked basins in Indonesia reveal high habitat diversity in anchialine systems. Hydrobiologia 677(1): 89-105. https://doi.org/10.1007/s10750-011-0742-0

Becking LE, Cleary DF, de Voogd NJ (2013) Sponge species composition, abundance, and cover in marine lakes and coastal mangroves in Berau, Indonesia. Marine Ecology Progress Series 481: 105-120. https://doi.org/10.3354/meps10155

Becking LE, de Leeuw CA, Knegt B, Maas DL, de Voogd NJ, Abdunnur, Suyatna I, Peijnenburg KTCA (2016) Highly divergent mussel lineages in isolated Indonesian marine lakes. PeerJ 4:e2496. https://doi.org/10.7717/peerj.2496

Boury-Esnault N, Rützler K (1997) Thesaurus of sponge morphology. Smithsonian Contributions to Zoology 596: 1-55. https://doi.org/10.5479/si.00810282.596

Burton M (1934) Sponges. Scientific Reports of the Great Barrier Reef Expedition 1928-1929 4(14): 513-621. 
Burton M (1959) Sponges. Scientific Reports of the John Murray Expedition 1933-34. British Museum Natural History of London 10(5): 151-281.

Calcinai B, Bastari A, Bavestrello G, Bertolino M, Bueno-Horcajadas S, Pansini M, Makapedua DM, Cerrano C (2017) Demosponge diversity from North Sulawesi, with the description of six new species. Zookeys 680: 105-150. https://doi.org/10.3897/zookeys.680.12135

Carella M, Agell G, Cárdenas P, Uriz MJ (2016) Phylogenetic reassessment of Antarctic Tetillidae (Demospongiae, Tetractinellida) reveals new genera and genetic similarity among morphologically distinct species. PLoS ONE 11(8): e0160718. https://doi.org/10.1371/ journal.pone.0160718

Carter HJ (1883) Contribution to our knowledge of the Spongida - Pachytragida. Annals and Magazine of Natural History (5) 11(65): 344-369. https://doi. org/10.1080/00222938309459163

Carter HJ (1886) Descriptions of sponges from the neighbourhood of Port Phillip Heads, South Australia, continued. Annals and Magazine of Natural History (5) 18: 34-55, 126149. https://doi.org/10.1080/00222938609459946

Cavalier-Smith T, Chao EE, Boury-Esnault N, Vacelet J (1996) Sponge phylogeny, animal monophyly, and the origin of the nervous system: $18 \mathrm{~S}$ rRNA evidence. Canadian Journal of Zoology 74: 2031-2045. https://doi.org/10.1139/z96-231

Cleary DF, Becking LE, Voogd NJD, Pires AC, Polónia AR, Egas C, Gomes NC (2013) Habitat-and host-related variation in sponge bacterial symbiont communities in Indonesian waters. FEMS Microbiology Ecology 85: 465-482. https://doi.org/10.1111/15746941.12135

Dawson MN, Hamner WM (2005) Rapid evolutionary radiation of marine zooplankton in peripheral environments. Proceedings of the National Academy of Sciences of the United States of America 102 (26): 9235-9240. https://doi.org/10.1073/pnas.0503635102

Dendy A (1905) Report on the sponges collected by Professor Herdman, at Ceylon, in 1902. In: Herdman WA (Ed.) Report to the Government of Ceylon on the Pearl Oyster Fisheries of the Gulf of Manaar 3 (Supplement 18) Royal Society, London, 57-246. [pls I-XVI]

Dendy A (1922) Report on the Sigmatotetraxonida collected by HMS 'Sealark' in the Indian Ocean. In: Reports of the Percy Sladen Trust Expedition to the Indian Ocean in 1905, Volume 7. Transactions of the Linnean Society of London (2) 18(1): 1-164. [pls 1-18]

Desqueyroux-Faundez R (1981) Révision de la collection d'éponges d'Amboine (Molusques, Indonésie) constituée par Bedot et Pictet et conservée au Muséum d'histoire naturelle de Genève. Revue Suisse de Zoologie 88: 723-764. https://doi.org/10.5962/bhl.part.82404

Fernandez JC, Kelly M, Bell LJ (2017) Cinachyrella anatriaenilla sp. nov., a new tetillid sponge with microacanthoxeas from American Samoa in the South Pacific. Zootaxa 4258(1): 81 https://doi.org/10.11646/zootaxa.4258.1.6

Fernandez JC, Rodriguez PRD, Santos GG, Pinheiro U, Muricy G (2018) Taxonomy of deep-water tetillid sponges (Porifera, Demospongiae, Spirophorina) from Brazil, with description of three new species and new characters. Zootaxa 4429(1): 53-88. https://doi. org/10.11646/zootaxa.4429.1.2

Gray JE (1873) On two new free sponges from Singapore. Annals and Magazine of Natural History (4) 11(63): 234-235. https://doi.org/10.1080/00222937308696805 
Hentschel E (1911) Tetraxonida. 2. Teil. In: Michaelsen W, Hartmeyer R (Eds) Die Fauna Südwest-Australiens. Ergebnisse der Hamburger südwest-australischen Forschungsreise 1905, 3(10), 279-393.

Hentschel E (1912) Kiesel-und Hornschwämme der Aru und Kei-Inseln. Hamburg: Abhandlungen Senckenbergiana Naturforschende Gessellschaft 34(3): 293-448. [pls 13-21]

Hooper JNA, Wiedenmayer F (1994) Porifera. In: Wells A (Ed.) Zoological Catalogue of Australia (Volume 12). CSIRO, Melbourne, 1-620.

Hooper JNA, Kennedy JA, van Soest RWM (2000) Annotated checklist of sponges (Porifera) of the South China Sea region. Raffles Bulletin of Zoology (Suppl.) 8: 125-207.

Hooper JNA, van Soest RWM (2002) Systema Porifera. Kluwier Publishing Company, UK, 1810 pp. https://doi.org/10.1007/978-1-4615-0747-5

Keller C (1891) Die Spongienfauna des Rothen Meeres (II. Hälfte). Zeitschrift für wissenschaftliche Zoologie 52: 294-368. [pls XVI-XX]

Kieschnick O (1896) Silicispongiae von Ternate nach den Sammlungen von Herrn Prof. Dr. W Kükenthal. Zoologischer Anzeiger 19(520): 526-534.

Kieschnick O (1898) Die Kieselschwämme von Amboina. PhD thesis, Inaugural Dissertation, University of Jena, Thuringia, Germany.

Kieschnick O (1900) Kieselschwämme von Amboina. In: Semon R (Ed) Zoologische Forschungsreisen in Australien und dem Malayischen Archipel Ausgesführt in den Jahren 18911893. Denkschriften der Medicinisch-Naturwissenschaftlichen Gesellschaft 8: 547-582.

Kirkpatrick R (1900) On the sponges of Christmas Island. Proceedings of the Zoological Society of London 1900: 127-141.

Kritsanapuntu S, Chaitanawisuti N, Yeemin T (2001a) A survey of the abundance and distribution patterns of the spherical sponge, Cinachyrella australiensis Carter 1886 on an intertidal rocky beach at Sichang Island, inner part of Eastern Gulf of Thailand. Asian Marine Biology 18: 163-170.

Kritsanapuntu S, Chaitanawisuti N, Yeemin T, Putchakan S (2001b) First investigation on biodiversity of marine sponges associated with reef coral habitats in the eastern Gulf of Thailand. Asian Marine Biology 18: 105-115.

Lamarck JBP De Monet, Comte De (1815) [1814] Suite des polypiers empâtés. Mémoires du Muséum d'Histoire naturelle, Paris 1: 69-80, 162-168, 331-340.

de Laubenfels MW (1954) The sponges of West Central Pacific. Oregon State College Press, Studies in Zoology 7: 1-306.

Lazoski C, Peixinho S, Russo CAM, Solé-Cava AM (1999) Genetic confirmation of the specific status of two sponges of the genus Cinachyrella (Porifera: Spirophorida: Demospongiae) in the Southwest Atlantic. Memoires Queensland Museum 44: 299-306.

Lendenfeld R von (1888) Descriptive catalogue of the sponges in the Australian Museum, Sidney. Taylor and Francis, London, 260 pp.

Lendenfeld R von (1903) Tetraxonia. In: Schulze FE (Ed.) Das Tierreich. Berlin, Friedländer Lf $19,1-168$.

Lendenfeld R von (1907) Die Tetraxonia. Wissenschaftliche Ergebnisse der Deutschen TiefseeExpedition auf der Dampfer Valdivia 1898-1899 11(1-2): 59-374.

Lim S-C, de Voogd NJ, Siang TK (2008) A guide to sponges of Singapore. Science Centre of Singapore, Singapore, $173 \mathrm{pp}$. 
Lindgren NG (1897) Beitrag zur Kenntniss der Spongienfauna des Malaiischen Archipels und der Chinesischen Meere. Zoologische Anzeiger 547: 480-487.

Lindgren NG (1898) Beitrag zur Kenntniss der Spongienfauna des Malayischen Archipels und der chinesischen Meere. Zoologische Jahrbücher, Abteilung für Systematik, Geographie und Biologie der Thiere 11: 283-378. [pls 17-20]

Longakit MBA, Sotto F, Kelly M (2005) The shallow water marine sponges (Porifera) of Cebu, Philippines. Science Diliman 17(2): 52-74.

McDonald JI, Hooper JNA, McGuinness KA (2002) Environmentally influenced variability in the morphology of Cinachyrella australiensis (Carter 1886) (Porifera: Spirophorida: Tetillidae). Marine and Freshwater Research 53: 79-84. https://doi.org/10.1071/MF00153

Mokhlesi A, Hartmann R, Kurtán T, Weber H, Lin W, Chaidir C, Müller WEG, Daletos G, Proksch P (2017) New 2-Methoxy acetylenic acids and pyrazole alkaloids from the marine sponge Cinachyrella sp. Marine drugs 15(11): 356.

Müller OF (1789) Zoologiae Danicae seu animalium Daniae et Norvegiae rariorum ac minus notorum descriptiones et historia. Havniae, Copenhague. Volumen tertium (1-2): 1-71. [pls. 81-120]

Pulitzer-Finali G (1982) [1980-1981] Some new or little-known sponges from the Great Barrier Reef of Australia. Bollettino dei Musei e degli Istituti Biologici della (R.) Università di Genova 48-49: 87-141.

Pulitzer-Finali G (1993) A collection of marine sponges from East Africa. Annales Museo Civico Storia Naturale "Giacomo Doria” 89: 247-350

Putchakarn S (2007) Species diversity of marine sponges dwelling in coral reefs in Had Khanom-Mo Ko Thale Tai National Park, Nakhon Si Thammarat Province, Thailand. Journal of the Marine Biological Association of the United Kingdom 87: 1635-1642. https://doi. org/10.1017/S002531540705833X

Ridley SO (1884) Spongiida. In: Report on the zoological collections made in the Indo-Pacific Ocean during the voyage of HMS 'Alert', 1881-2. British Museum Natural History, London, 366-482 [pls 39-43], 582-630 [pls 53-54].

Row RWH (1911) Report on the sponges collected by Mr. Cyril Crossland in 1904-05. Part II. Non-Calcarea. Journal of the Linnean Society of London, Zoology 31: 287-400. https://doi.org/10.1111/j.1096-3642.1911.tb00461.x

Rützler K (1987) Tetillidae (Spirophorida, Porifera): A taxonomic re-evaluation. In: Vacelet J, Boury-Esnault N (Eds) Taxonomy of Porifera from the NE Atlantic and Mediterranean Sea. NATO ASI Series Vol. G13. Springer-Verlag, Berlin, 187-203.

Rützler K, Smith KP (1992) Guide to western Atlantic species of Cinachyrella (Porifera: Tetillidae). Proceedings of the Biological Society of Washington 105(1): 148-164.

Schönberg CHL (2015) Happy relationships of marine sponges with sediments-a review and some observations from Australia. Journal of the Marine Biological Association of the United Kingdom 96: 493-514. https://doi.org/10.1017/S0025315415001411

Schuster A, Lopez JV, Becking LE, Kelly M, Pomponi SA, Wörheide G, Erpenbeck D, Cárdenas P (2017) Evolution of group I introns in Porifera: new evidence for intron mobility and implications for DNA barcoding. BMC evolutionary biology 17(1), 82: 1-21.

Selenka E (1867) Ueber einige neue Schwämme aus der Südsee. Zeitschrift für wissenschaftliche Zoologie 17(3): 565-571 
Singh A, Thakur NL (2015) Field and laboratory investigations of budding in the tetillid sponge Cinachyrella cavernosa. Invertebrate biology 134(1): 19-30. https://doi.org/10.1111/ ivb. 12074

van Soest RWM (1977) A revision of the megacanthoxea-bearing tetillids (Porifera, Spirophorida), with a description of a new species. In: Hummelinck PW, van der Steen LJ (Eds) Uitgaven van de Natuurwetenschappelijke Studiekring voor Suriname en de Nederlandse Antillen. No. 89. Studies on the Fauna of Curaçao and other Caribbean Islands 53(172): 1-14. van Soest RWM, Hooper JNA (2002) Order Spirophorida Bergquist and Hogg, 1969. In: Hooper JNA, van Soest RWM (Eds) Systema Porifera - A Guide to the Classification of Sponges (Volume 1). 83-84.

van Soest RWM, Rützler K (2002) Family Tetillidae Sollas, 1888. In: Hooper JNA, van Soest RWM (Eds) Systema Porifera: a guide to the classification of sponges. Kluwer, Plenum, New York, 85-98. https://doi.org/10.1007/978-1-4615-0747-5_8

van Soest RWM, Beglinger EJ(2008) Tetractinellid and hadromerid sponges from the Sultanate of Oman. Zoölogische Mededelingen Leiden 82(53): 749-790.

van Soest RWM, Boury-Esnault N, Hooper JNA, Rützler K, de Voogd NJ, Alvarez B, Hajdu E, Pisera AB, Manconi R, Schönberg C, Klautau M, Picton B, Kelly M, Vacelet J, Dohrmann M, Díaz MC, Cárdenas P, Carballo JL, Ríos P, Downey R (2018) World Porifera database. Cinachyrella australiensis (Carter, 1886). http://www.marinespecies.org/porifera/porifera. php?p=taxdetails\&id=171296 [2018-06-07]

van Soest RWM, Boury-Esnault N, Hooper JNA, Rützler K, de Voogd NJ, Alvarez B, Hajdu E, Pisera AB, Manconi R, Schönberg C, Klautau M, Picton B, Kelly M, Vacelet J, Dohrmann M, Díaz MC, Cárdenas P, Carballo JL, Ríos P, Downey R (2018) World Porifera database. Paratetilla bacca (Selenka, 1867). http://www.marinespecies.org/porifera/porifera. php?p=taxdetails\&id=171366 [2018-06-07]

Sollas IBJ (1902) On the sponges collected during the 'Skeat Expedition' to the Malay Peninsula 1899-1900. Proceedings of the Zoological Society of London 2: 210-221.

Sollas WJ (1888) Report on the Tetractinellida collected by HMS Challenger, during the years 1873-1876. Report of the Scientific Results of the Voyage of HMS “Challenger”, 18731876, Zoology 25(63): 1-458.

Szitenberg A, Becking LE, Vargas S, Fernandez JC, Santodomingo N, Wörheide G, Ilan M, Kelly M, Huchon M (2013) Phylogeny of Tetillidae (Porifera, Demospongiae, Spirophorida) based on three molecular markers. Molecular phylogenetics and evolution 67(2): 509-519.

Topsent E (1897) Spongiaires de la Baie d'Amboine. (Voyage de MM M Bedot et C Pictet dans l'Archipel Malais). Revue Suisse de Zoologie 4: 421-487. https://doi.org/10.5962/ bhl.part.35507

Thiele J (1899) Studien über pazifische Spongien. II. Ueber einige Spongien von Celebes. Zoologica 24: 1-33.

Thiele J (1900) Kieselschwämme von Ternate. I. Abhandlungen herausgegeben von der Senckenbergischen naturforschenden Gesellschaft, Frankfurt 25: 19-80.

Thiele J (1903) Kieselschwämme von Ternate. II. Abhandlungen herausgegeben von der Senckenbergischen naturforschenden Gesellschaft, Frankurfurt 25: 933-968. 
Thomas PA (1973) Marine demospongiae of Mahé Island in the Seychelles Bank (Indian Ocean). Annales du Musée royal de l'Afrique centrale. Sciences zoologiques 203: 1-96.

Vacelet J, Vasseur P, Lévi C (1976) Spongiaires de la pente externe des récifs coralliens de Tuléar (Sud-Ouest de Madagascar). Mémoires du Muséum national d'Histoire naturelle (A, Zoologie) 49:1-116.

de Voogd NJ, van Soest RWM (2007) Acanthotetilla celebensis sp. nov., a new species from

North Sulawesi, Indonesia (Porifera: Demospongiae: Spirophorida: Tetillidae). Zootaxa 1397: 25-28. https://doi.org/10.11646/zootaxa.1397.3

de Voogd NJ, Cleary DFR (2008) An analysis of sponge biodiversity and distribution at three taxonomic levels in the Thousand Islands/Jakarta Bay reef complex, West-Java, Indonesia. Marine Ecology-An Evolutionary Perspective 29(2): 205-215. https://doi.org/10.1111/ j.1439-0485.2008.00238.x

de Voogd NJ, Becking LE, Cleary DFR (2009) Sponge community composition in Derawan Islands, NE Kalimantan, Indonesia. Marine Ecology Progress Series 396: 169-180. https://doi.org/10.3354/meps08349

Vosmaer GCJ (1887) Spongien (Porifera). In: Bronn HG (Ed.) Die Klassen und Ordnungen des Thierreichs 2. 1-496. [pls. I-XXXIV]

Wilson HV (1925) Silicious and horny sponges collected by the U.S. Fisheries steamer Albatross during the Philippine Expedition, 1907-10 - Contributions to the biology of the Philippine Archipelago and adjacent regions. Bulletin of the United States National Museum 100(2/4): 273-532.

Zhang H, Zhao Z, Wang H (2017) Cytotoxic natural products from marine sponge-derived microorganisms. Marine Drugs 15: 68. https://doi.org/10.3390/md15030068

\section{Supplementary material I}

\section{Table S1. Full collection details of each sample}

Authors: Nadiezhda Santodomingo, Leontine E. Becking

Data type: species data

Copyright notice: This dataset is made available under the Open Database License (http://opendatacommons.org/licenses/odbl/1.0/). The Open Database License $(\mathrm{ODbL})$ is a license agreement intended to allow users to freely share, modify, and use this Dataset while maintaining this same freedom for others, provided that the original source and author(s) are credited.

Link: https://doi.org/10.3897/zookeys.791.27546.suppl1 


\section{Supplementary material 2}

\section{Figure S1. Type material of Tethya merguiensis}

Authors: Nadiezhda Santodomingo, Leontine E. Becking

Data type: multimedia

Explanation note: NHMUK 1894.11.16.17, Mergui Archipelago, Myanmar. A two slide preparations of the type specimen $\mathbf{B}$ skeleton, showing anatriaenes and oxeas $\mathbf{C}$ oxea, anatriaene, and protriaene $\mathbf{D}$ thin microxeas and sigmaspires $\mathbf{E}$ sigmaspires. Scale bars: $100 \mu \mathrm{m}(\mathbf{B}, \mathbf{D}) ; 50 \mu \mathrm{m}(\mathbf{C}) ; 20 \mu \mathrm{m}(\mathbf{E})$.

Copyright notice: This dataset is made available under the Open Database License (http://opendatacommons.org/licenses/odbl/1.0/). The Open Database License $(\mathrm{ODbL})$ is a license agreement intended to allow users to freely share, modify, and use this Dataset while maintaining this same freedom for others, provided that the original source and author(s) are credited.

Link: https://doi.org/10.3897/zookeys.791.27546.suppl2 